\title{
Kaksisuuntainen katu
}

Poliitikot osallistujina

puntaroivassa kansalaiskeskustelussa

Niin se oli tavallaan kaksisuuntainen katu siltä osin, et me saatiin tietoa, mut me pystyttiin myös sitä antamaan.

Turku keskustelee -kansalaispaneeliin osallistunut kaupunginvaltuutettu

\author{
MIKKO VÄRTTÖ \\ MAIJA JÄSKE \\ KAISA HERNE \\ KIMMO GRÖNLUND
}

TIIVISTELMÄ Demokratiatutkijat pohtivat parhaillaan, miten puntaroivat kansalaiskeskustelut voitaisiin kytkeä perinteiseen edustukselliseen päätöksentekoon. Tutkimuskirjallisuudessa on esitetty, että poliitikkojen osallistuminen puntaroiviin kansalaiskeskusteluihin voisi vahvistaa puntaroivien kansalaiskeskustelujen kytköstä demokraattiseen päätöksentekoon. Tutkimme Turussa järjestetyn puntaroivan kansalaispaneelin avulla, miten poliitikkojen ja kansalaisten yhteinen keskustelu onnistuu ja miten poliitikot sen kokevat. Poliitikkojen osallistumisen on väitetty muun muassa vahvistavan poliitikkojen sitoutumista kansalaiskeskustelujen pohjalta tuotettuihin suosituksiin sekä lisäävän heidän intressiään edistää suosituksia päätöksenteossa. Toistaiseksi politiikkojen osallistumista puntaroiviin kansalaiskeskusteluihin on kuitenkin tutkittu hyvin vähän.

Lisätäksemme tietoa keinoista vahvistaa kytköksiä puntaroivien kansalaiskeskustelujen ja vaalidemokratian instituutioiden välillä tutkimme, kuinka kaupunginvaltuutettujen osallistuminen vaikutti Turku keskustelee -kansalaispaneelin työskentelyyn. Lisäksi tutkimme, kuinka valtuutetut kokivat osallistumisensa paneeliin sekä miten he suhtautuvat kuntalaisten suoraan poliittiseen osallistumiseen. Kansalaispaneeli järjestettiin toukokuussa 2020 ja siihen osallistui 171 kuntalaista sekä 21 valtuutettua. Paneelin aiheena oli kaupungin keskustan liikennejärjestelyt, ja paneelin jälkeen osallistujat äänestivät kolmen erilaisen skenaarion välillä.

Tutkimusta varten haastattelimme 11 paneeliin osallistunutta valtuutettua sekä teimme kyselyn, johon vastasi 17 valtuutettua ja 171 kuntalaista. Tutkimuksemme osoittaa, että valtuutettujen osallistuminen ei vaikuttanut kielteisesti puntaroivaan keskusteluun kansalaispaneelissa. Keskustelun aikana valtuutetut saivat lisää tietoa kuntalaisten toiveista ja tarpeista. Lisäksi keskustelu vahvisti valtuutettujen käsitystä kuntalaisten asiantuntijuudesta sekä kyvystä osallistua päätöksentekoon ja muodostaa valistuneita mielipiteitä. Valtuutetut myös suhtautuivat myönteisesti ajatukseen puntaroivien kansalaispaneelien käytöstä valtuustotyön tukena jatkossakin. 


\section{JOHDANTO}

Viime vuosina on tutkittu laajasti niin kutsuttujen demokraattisten innovaatioiden mahdollisuutta täydentää poliittista järjestelmää ja tuoda siihen yhtäältä osallistuvan demokratian ja toisaalta deliberatiivisen eli puntaroivan demokratian elementtejä (Warren 2009; 2017). Demokraattisilla innovaatioilla tarkoitetaan menettelyjä, joiden tavoitteena on lisätä ja syventää kansalaisten osallistumista poliittiseen päätöksentekoon (Smith 2009). Viime vuosina empiirisesti tutkituimmaksi innovaatioksi on noussut satunnaisotokseen perustuva puntaroiva kansalaiskeskustelu, josta käytetään usein nimitystä mini-demos (mini-public). Satunnaisotoksen perusteella muodostettu mini-demos on pieni otos kansasta, mutta edustaa sen moninaisuutta (Grönlund ym. 2014).

Aikaisemmat tutkimukset ovat osoittaneet, että puntaroivat kansalaiskeskustelut jäävät usein irralliseksi muista poliittisista areenoista (Curato ja Böker 2016; Svensson 2008). Tutkijoita askarruttaakin, miten kansalaiskeskusteluja voitaisiin linkittää vaalidemokratiaan perustuvaan järjestelmään. Yksi ehdotetuista keinoista on poliittisten päättäjien osallistuminen kansalaiskeskusteluihin (Farrell ym. 2020). Esimerkiksi Irlannissa, Isossa-Britanniassa ja Belgiassa on kokeiltu tämän tyyppistä "hybridimallia" (Aarninsalo ym. 2020). Tutkimukset ovat osoittaneet, että poliitikoiden mukaan ottamisella voi olla myönteisiä vaikutuksia keskusteluiden laadulle ja tuloksille (Farrell 2014, 114). Toisaalta poliitikkojen ja tavallisten kansalaisten välinen keskustelu ei ole välttämättä tasa-arvoista puntaroivan demokratian ideaalin edellyttämällä tavalla (Mansbridge ym. 2010).

Me kysymme, miten poliitikkojen osallistuminen vaikuttaa puntaroiviin kansalaiskeskusteluihin ja miten poliitikot kokevat oman osallistumisensa keskusteluihin. Tutkimustamme varten järjestimme puntaroivan demokratian mallin mukaisen Turku keskustelee -kansalaispaneelin toukokuussa 2020 yhteistyössä Turun kaupungin kanssa. Kansalaispaneelissa 171 kuntalaista ja 21 kaupunginvaltuuston jäsentä keskustelivat Turun kaupungin keskustan liikennejärjestelyistä, minkä jälkeen paneeliin osallistuneet kuntalaiset äänestivät kolmen erilaisen skenaarion välillä. Kansalaispaneelin äänestystulos vietiin osaksi yleiskaavan valmistelua kaupungin päätöksentekoelimissä.

Haastattelimme tutkimusta varten yhtätoista kaupunginvaltuutettua, jotka osallistuivat Turku keskustelee -kansalaispaneeliin. Tavoitteemme oli kartoittaa keskusteluihin osallistuneiden valtuutettujen motivaatiota osallistua, kokemuksia osallistumisesta sekä näkemyksiä vastaavien osallistumismuotojen käytöstä laajemmin. Pyrimme haastattelujen avulla selvittämään mitä poliitikot ajattelevat osallistumisesta puntaroiviin kansalaiskeskusteluihin yhdessä kansalaisten kanssa sekä niiden roolista päätöksenteossa. Täydensimme haastatteluaineistoa osallistuneille valtuutetuille ja kuntalaisille tehdyillä kyselyillä. Kuntalaiskyselyllä selvitimme kuntalaisten kokemusta keskusteluista sekä valtuutettujen roolista niissä.

On huomioitavaa, että tarkastelemme puntaroivan demokratian toteutumista pelkästään puntaroivissa kansalaiskeskusteluissa, emme laajemmassa merkityksessä, jossa puntaroivan demokratian nähdään toteutuvan julkisessa keskustelussa erilaisilla keskusteluareenoilla (esim. Habermas 2006). Emme myöskään viittaa puntaroivilla kansalaiskeskusteluilla keskusteluihin parlamentaarisissa päätöksentekoelimissä, vaikka ne ovat merkittäviä poliittisen argumentoinnin areenoita (Steiner ym. 2004). Sen sijaan tässä artikkelissa tarkoitamme puntaroivilla 
kansalaiskeskusteluilla sellaisia puntaroivan demokratian periaatteille perustuvia suoran kansalaisosallistumisen muotoja, joihin kansalaiset osallistuvat päätöksentekoon suoraan ilman, että osallistuminen kanavoituisi puolueiden, poliitikkojen tai järjestöjen kautta. Lisäksi tarkastelemme nimenomaan hallintolähtöistä osallistumista, joka on yhteydessä käynnissä olevaan suunnitteluja päätöksentekoprosessiin. Tämä voidaan määritellä institutionaaliseksi osallistumiseksi, jossa kansalaisosallistuminen tapahtuu hallinnon määrittämissä puitteissa, eikä esimerkiksi vapaaehtoistyön, kansalaisaktivismin tai muun kansalaislähtöisen osallistumisen kautta (Jäntti ym. 2016).

Seuraavaksi esittelemme puntaroivan demokratian teoriaa sekä pohdimme tutkimuskirjallisuuden pohjalta, millaisia mahdollisia haasteita poliitikkojen osallistuminen kansalaiskeskusteluihin asettaa puntaroivan demokratian periaatteiden toteutumiselle. Tämän jälkeen esittelemme Turku keskustelee -kansalaispaneelin taustaa ja toteutusta. Tutkimusaineisto, analyysimenetelmät ja tutkimustulokset esitellään seuraavaksi. Johtopäätökset tiivistävät tärkeimmät tuloksemme. Tutkimuksen lopussa pohdimme vielä puntaroivien kansalaiskeskustelujen edellytyksiä toimia osana kuntahallintoa.

\section{PUNTAROIVA DEMOKRATIA}

Puntaroiva demokratia viittaa poliittiseen päätöksenteon ihanteelliseen malliin, jossa päätökset tehdään tietoperusteisen argumentoinnin varassa. Puntaroivan keskustelun kriteereinä ovat tasavertaisuus ja toisten kunnioitus (Gutmann ja Thompson 1996). Puntaroivassa keskustelussa osallistujat ovat valmiita muuttamaan mielipidettään, mikäli toiset keskustelijat saavat heidät vakuutettua argumenteillaan (Habermas 1975, 108), tai keskustelu antaa heille tietoa, joka kumoaa heidän aikaisemmat käsityksensä (Mansbridge ym. 2010). Puntaroivan demokratian ihanteen mukaan mielipiteitä arvioidaan vain sillä perusteella, miten hyvin ne on perusteltu, eikä esittäjän taustan tai aseman mukaan (Dryzek 2000, 2). Tavoitteena on, että osallistujat pystyvät irtautumaan yksityisiin intresseihinsä perustuvista vaatimuksista ja löytämään ratkaisuja, jotka kaikki osallistujat voivat hyväksyä (Dryzek 2001, 651).

Kiinnostus puntaroivaa demokratiaa kohtaan on vahvistunut viime vuosikymmenien aikana, sillä sen on nähty vastaavan joihinkin demokraattisten järjestelmien ongelmiin, kuten äänestysaktiivisuuden laskuun, heikkenevään poliittiseen luottamukseen ja vahvistuvaan polarisaatioon (Grönlund ym. 2010; 2015). Puntaroivan demokratian kannattajien mukaan se vastaa demokraattisen päätöksenteon ihannetta tuoden esiin todellisen "kansan tahdon" (Bohman 1998, 401). Puntaroivan demokratian keskeinen sanansaattaja James Fishkin (2009) puhuu harkitusta kansalaismielipiteestä, joka poikkeaa mielipidetiedusteluissa selvitetyistä nopeista reaktioista. Puntaroivassa demokratiassa pyrkimyksenä on kuulla erilaisia näkemyksiä, sovittaa niitä yhteen sekä saavuttaa yhteisymmärrys. Juuri pyrkimys erilaisten näkökulmien yhteensovittamisesta sekä yhteisymmärryksen saavuttamisesta erottaa puntaroivan demokratian sellaisista malleista, joissa demokraattiset päätökset tehdään erilaisten vaihtoehtojen välillä äänestämällä tai neuvottelemalla (Fung 2006). Puntaroivan keskustelun avulla voidaan päästä irti populismista, joka voi perustua tiedon vääristelyyn, lyhytjänteisyyteen tai vaadittujen ratkaisujen kustannusten ohittamiseen. 
Puntaroivaa demokratiaa ja sen käytännön sovelluksia on myös kritisoitu (esim. Sanders 1997; Young 2000). Ehkä painavin kritiikki liittyy siihen, miksi niiden kansalaisten, jotka eivät osallistu keskusteluun, pitäisi hyväksyä keskustelun perusteella muodostettu harkittu kansalaismielipide (Chambers 2009; Lafont 2017; Parkinson 2006). Vastineeksi on esitetty, että kansalaispaneelit eivät välttämättä sovikaan tuottamaan suoraan poliittisia päätöksiä, vaan pikemminkin tietoa, jota kansalaiset voivat arvioida ja käyttää oman mielipiteenmuodostuksensa tukena (Bächtiger ja Goldberg 2020).

Puntaroiva demokratia lähti liikkeelle teoreettisesta keskustelusta, mutta myöhemmin heräsi kiinnostus testata empiirisesti, miten ideaali voitaisiin käytännössä tavoittaa. Maailmalla onkin kehitetty useita erilaisia puntaroivan demokratian mallin mukaisia menetelmiä (Aarninsalo ym. 2020; Elstub 2014; Setälä ja Smith 2018). ${ }^{1}$ Puntaroiva kansalaiskokous (Citizens' Assembly) kokoaa yhteen suuren joukon kansalaisia keskustelemaan jostain teemasta, mutta varsinaista päätösvaltaa kansalaiskokouksella ei ole, vaan se tarjoaa tukea vaalidemokratian kautta tapahtuvalle päätöksenteolle (Elstub 2014). Puntaroivassa mielipidemittauksessa (Deliberative Poll) satunnaisotoksella valitut kansalaiset saavat puolueetonta tietoa ja keskustelevat pienryhmissä. Tutkimuksellisen mielenkiinnon kohteena on harkittu kansalaismielipide, eli tiedon lisääntyminen ja pienryhmäkeskusteluissa muodostunut mielipide (Elstub 2014; Fishkin 1991).

Merkittävä osa puntaroivan demokratian käytännön toteutuksista perustuu siihen, että osallistujat valitaan satunnaisotannalla, jossa kullakin kansalaisella on yhtäläinen mahdollisuus tulla kutsutuksi kansalaiskeskusteluun. Satunnaisotantaan perustuva osallistuminen erottaa kansalaispaneelit ja muut vastaavat mallit vaaleilla valituista instituutioista. Osallistujat eivät voi ammattimaistua eikä heidän ympärilleen voi muodostua puolueiden kaltaisia ryhmittymiä. Vaalidemokratiassa edustaminen perustuu kansalaisten vaaleissa antamaan valtuutukseen tehdä muita koskevia päätöksiä. Myös kansalaispaneeli voi tehdä päätöksiä tai antaa tukea muiden kuin osallistujien mielipiteenmuodostukseen, jolloin on myös kyse edustamisesta siinä mielessä, että poliittista toimivaltaa käytetään muiden puolesta. Tutkijat ovat kutsuneet suoran kansalaisosallistumisen mallien edustuksellisuutta kansalaisedustamiseksi (Warren 2008) tai demokraattiseksi edustamiseksi (Landemore 2020, 55-56, 86-87). Kansalaisedustamisen oleellisin piirre on se, että pääsy edustajan asemaan on avoinna kaikille tavallisille kansalaisille yhtäläisesti, eikä riipu esimerkiksi yksilön asiantuntemuksesta tai kampanjaan käytettävissä olevista resursseista.

Tutkimukset osoittavat, että puntaroiva kansalaiskeskustelu voi vahvistaa kansalaisten osallistumista julkiseen päätöksentekoon. Kansalaiskeskustelut voivat johtaa osallistujien mielipiteiden muutoksiin, vahvistaa luottamusta demokraattisiin instituutioihin sekä kehittää kansalaistaitoja (Grönlund ym. 2010; Grönlund ym. 2015). Kansalaiskeskustelut auttavat kansalaisia muodostamaan preferenssejään (Gastil ym. 2018; List ym. 2013), lisäävät heidän tietotasoaan (Gastil ym. 2018) sekä ehkäisevät mielipiteiden polarisaatiota (Grönlund ym. 2015). Toisaalta empiiriset tutkimukset kansalaiskeskustelujen vaikutuksista päätöksiin ovat tuottaneet ristiriitaisempia tuloksia. Irlannissa kansalaiskokouksen suositukset koskien muun muassa aborttilainsäädännön, avioliittolainsäädännön ja vaalijärjestelmän uudistamista hyväksyttiin kansanäänestyksissä ja siten voidaan ajatella, että kansalaiskokouksella oli laajempaakin vaikutusta (Farrell ym. 2020; Suiter 2018). Esimerkiksi Irlannin aborttilainsäädännön tapauksessa 66 prosenttia äänestäjistä oli tietoisia kansalaiskokouksen suosituksista (Suiter 2018). Toisaalta Alankomaissa ja Kanadassa kansalaiskokousten tulokset eivät juurikaan vaikuttaneet tehtyihin päätöksiin (Fournier ym. 2011). 
Viime aikoina demokratiatutkijoiden keskuudessa on virinnyt keskustelu siitä, kuinka kansalaiskeskustelujen vaikutuksia kollektiivisiin päätöksiin voitaisiin vahvistaa. Skaalaaminen, (scaling up), viittaa puntaroivien kansalaiskeskustelujen vaikutuksen lisäämiseen laajemman yleisön keskuudessa (Niemeyer 2014). Ajattelu pohjautuu niin sanottuun systeemiseen käsitykseen puntaroivasta demokratiasta, jossa erilaiset kansalaiskokoukset ja -raadit sekä muut keskustelun tilat ja paikat nähdään osana laajempaa järjestelmää (Mansbridge 1999). Kansalaiskeskustelujen skaalaamisen tavoitteena on rikastuttaa julkista keskustelua tuomalla puntaroituja kansalaismielipiteitä asiantuntijoiden ja poliittisten päättäjien esittämien kantojen rinnalle.

Puntaroivan demokratian institutionalisoinnilla tarkoitetaan puntaroivien kansalaiskeskustelujen integroimista osaksi olemassa olevia päätöksentekoprosesseja. Institutionalisointia edustaa esimerkiksi ajatus kansalaisraatien perustamista osaksi valiokuntien toimintaa (Hendriks 2016; Hendriks ja Kay 2019). Raadit voivat tarjota valiokunnille puntaroituja kansalaismielipiteitä erilaisista käsiteltävistä asioista. Kirjallisuudessa on esitetty myös muita tapoja, joiden avulla kytköstä politiikan eri areenoiden välillä voidaan vahvistaa. Puntaroivat kansalaiskeskustelut voidaan institutionalisoida vahvemmin osaksi poliittista järjestelmää kutsumalla poliitikot mukaan kansalaiskeskusteluihin yhdessä kansalaisten kanssa tai velvoittamalla heitä ottamaan julkisesti kantaa kansalaiskeskusteluun osallistuneiden kansalaisten esittämiin toimenpidesuosituksiin (Setälä 2017). On myös esitetty, että puntaroivien kansalaiskeskustelujen ja muun demokraattisen järjestelmän välinen kytkös voisi vaihdella riippuen siitä, miten hyvin vaalidemokratia toimii. Kansalaiskeskusteluja tarvittaisiin erityisesti silloin, kun vaalidemokratiaan perustuva järjestelmä ei ota kattavasti huomioon kaikkia kansalaisryhmiä ja heidän näkemyksiään (Kuyper ja Wolkenstein 2018).

Vaikka teoriakirjallisuudessa on esitetty erilaisia tapoja kytkeä puntaroivan kansalaiskeskustelun ja vaalidemokratian areenoja (Boswell ym. 2016; Setälä 2017), empiiristä tutkimusta tästä kytköksestä on toistaiseksi vähän (Farrell 2014; Farrell ym. 2020; Flinders ym. 2016; Hendriks 2016; Hendriks ja Kay 2019). Tavoitteemme onkin täydentää olemassa olevaa tietoa tutkimalla erityisesti poliitikkojen osallistumista puntaroivaan kansalaiskeskusteluun. Tarkastelemme seuraavaksi, millaisia mahdollisuuksia ja haasteita poliitikkojen osallistumisella on puntaroivien kansalaiskeskustelujen onnistumiselle.

\section{POLIITIKOT MUKANA KANSALAISPANEELISSA}

Tutkimus viittaa siihen, että puntaroivan kansalaiskeskustelun muodolla on suuri merkitys keskustelujen onnistumiselle (Pearse 2008). Yksi merkittävä tekijä näyttäisi olevan se, osallistuuko keskusteluihin pelkästään kansalaisia vai myös asiantuntijoita, politiikkoja tai eri intressiryhmien edustajia (White 2017). Pääsääntöisesti erilaisten intressiryhmien edustajat ovat voineet osallistua puntaroiviin kansalaiskeskusteluihin pelkästään asiantuntijaroolissa, jolloin he ovat voineet vaikuttaa muun muassa siihen, millaisella tiedolla kansalaiskeskustelua pohjustetaan. Intressiryhmät ovat myös voineet julkistaa kansalaiskeskustelujen tuottamia suosituksia tai osallistua niiden toteuttamiseen (Hendriks 2006). Maailmalla on kuitenkin esimerkkejä myös hybridimalleista, joissa itse puntarointiin on osallistunut muitakin kuin kansalaisia. Esimerkiksi Irlannin perustuslain uudistusta käsittelevässä kansalaiskokouksessa kolmasosa osallistujista oli 
poliitikkoja (Farrell 2014), ja Brysselin alueparlamentin hiljattain perustamissa puntaroivissa komiteoissa kolme neljäsosaa 60 jäsenestä on tavallisia kansalaisia ja yksi neljäsosa parlamentaarikkoja (Niessen ja Reuchamps 2019).

Voiko asiantuntijoiden tai poliitikkojen kansalaispaneeliin osallistumiseen liittyä jotain ongelmia? Osallistujien tasavertaisuutta on yleensä pidetty puntaroivan demokratian edellytyksenä (Mansbridge ym. 2010). Yhtenä argumenttina eri valta-asemassa olevien ihmisten samanaikaista osallistumista vastaan voidaan pitää sitä, että hallitsevassa asemassa olevilla ihmisillä voi olla paremmat kyvyt ja taidot omien kantojensa esittämiseen sekä niiden perustelemiseen. Poliitikot saattavat olla kansalaisia taitavampia keskustelijoita ja heillä voi myös olla poliittiseen prosessiin ja käsiteltävään teemaan liittyvää tietoa kansalaisia enemmän. Poliitikoille kannanottojen esittäminen ja perusteleminen julkisuudessa ja päätöksenteon areenoilla on oleellinen osa heidän jokapäiväistä työtään. Poliitikoilla on siten paremmat valmiudet tuoda esiin omia kantojaan keskusteluissa sekä hankkia niille tukea muilta keskustelijoilta. Tämä voi johtaa poliitikkojen "älylliseen dominointiin" (intellectual domination) keskusteluissa (Vandamme ym. 2018).

Poliitikkojen osallistumista puntaroivan demokratian malleihin voidaan pitää ongelmallisena myös siksi, että poliitikkojen tehtävänä on edistää erilaisia intressejä käyttäen hyödyksi kaikkia tarjolla olevia työkaluja (Bengtsson ja Wass 2011; Esaiasson 2000). Tämä tarkoittaa, että poliitikot saattavat hyödyntää myös puntaroivia kansalaiskeskusteluja edustaakseen keskusteluissa tietynlaisia intressejä. Martin Karlssonin (2012) mukaan poliitikot voivat ymmärtää edustajuuden kolmella eri tavalla. Poliitikko voi toimia ennen kaikkea oman puolueensa edustajana, jolloin hän saattaa nostaa esiin edustamansa puolueen näkemyksiä vahvistaakseen puolueensa profiilia keskusteluissa käsitellyissä kysymyksissä. Poliitikot voivat myös toimia edistääkseen omien äänestäjiensä preferenssejä ja tuoda heidän toiveitaan esiin, vaikka ne eivät vastaisikaan poliitikon edustaman puolueen linjaa. Poliitikoilla voi olla myös oman puolueensa poliittisista linjauksista tai äänestäjien preferensseistä eroavia henkilökohtaisia poliittisia intressejä, joten he saattavat osallistua kansalaiskeskusteluihin myös edistääkseen henkilökohtaisia poliittisia tavoitteitaan ja nostaakseen poliittista profiiliaan keskusteluissa käsitellyissä kysymyksissä. Näin poliitikot saattavat käyttää kansalaiskeskusteluun osallistumista tai siihen liittyvää julkisuutta edistääkseen urallaan etenemistä tai muita henkilökohtaisia tavoitteitaan (Hendriks 2016). Poliitikot saattavat siis hyödyntää puntaroivia kansalaiskeskusteluja tavoilla, joita voidaan pitää osittain vastakkaisina puntaroivan keskustelun periaatteille.

Poliitikkojen osallistumisella puntaroivan demokratian keskusteluihin voi kuitenkin olla päätöksenteon kannalta myös myönteisiä vaikutuksia. Keskusteluihin osallistuessaan poliitikot voivat saada kansalaisilta arvokasta tietoa siitä, mitkä seikat kansalaiset kokevat tärkeiksi, millaisia ratkaisuja he pitävät oikeudenmukaisina ja millaiset ratkaisut todennäköisesti myös toimivat kansalaisten arjessa. Poliitikkojen osallistuminen myös vahvistaa keskusteluiden annin kulkeutumista vaalidemokratian suunnittelu- ja päätöksentekojärjestelmiin (Flinders ym. 2016). Kun poliittiset päätöksentekijät osallistuvat puntaroivan kansalaiskeskustelun julkilausumien muotoiluun, heillä on suurempi intressi edistää kansalaiskeskustelun huomioimista vaalidemokratiaan perustuvassa päätöksenteossa (Setälä 2017; Vandamme ym. 2018). Poliitikot voivat myös tuoda keskusteluihin lisää tietoa keskustelluista asiakysymyksistä. Poliitikkojen tieto poliittisista prosesseista taas voi auttaa keskustelun julkilausuman muotoilemista siten, että sillä on parempi mahdollisuus tulla huomioiduksi tehtävissä päätöksissä. 
Näkemykset poliitikkojen osallistumisen myönteisistä vaikutuksista ovat saaneet osittaista tukea eri puolilla maailmaa järjestetyistä puntaroivan demokratian sovelluksista. Poliitikkojen osallistuminen esimerkiksi tukee keskusteluiden tulosten huomioimista päätöksenteossa antamalla niille enemmän poliittista painoarvoa ja edistämällä näin keskusteluiden tulosten etenemistä päätöksentekoprosesseissa (Farrell 2014, 114). Systemaattisimmin poliitikkojen osallistumista on tutkittu Isossa-Britanniassa vuonna 2015 toteutetussa kansalaiskeskustelussa, jossa verrattiin pelkästään kansalaisista koostuvia keskusteluryhmiä kansalaisista ja poliitikoista koostuviin ryhmiin (Farrell ym. 2020). Vertailu osoitti, että vaikka jälkimmäisiin osallistuneet kansalaiset olivat taipuvaisempia tuntemaan, että jotkut keskustelijat hallitsivat keskusteluja, kokemuksen todettiin vähentyneen seuraavilla tapaamiskerroilla (Flinders ym. 2016). Varsinkin pitkällä aikavälillä poliitikkojen osallistumisen mahdolliset haitalliset vaikutukset keskusteluihin jäivät vastaajien mukaan vähäisiksi.

Aikaisempi tutkimus poliitikkojen osallistumisesta on keskittynyt kansalaisten kokemuksiin, kun taas puntaroiviin kansalaiskeskusteluihin osallistuneiden poliitikkojen kokemuksia ei ole juurikaan tutkittu. Tosin Irlannin kansalaiskokousta koskeva tutkimus osoitti, että keskusteluihin osallistuneet poliitikot olivat asenteiltaan vasemmistolaisempia ja liberaalimpia kuin kollegansa, jotka eivät osallistuneet keskusteluihin (Farrell ym. 2020, 14). Tutkimuksessa on myös aikaisemmin todettu, että puoluekentällä vasemmistopuolueet ovat oikeistopuolueita myönteisempiä kansalaisten osallistumista kohtaan (Núñez ym. 2016; Sintomer ym. 2008). Saattaakin olla, että keskusteluihin osallistuvat poliitikot suhtautuvat jo lähtökohtaisesti muita myönteisemmin suoraan kansalaisosallistumiseen. Kielteisemmin kansalaisosallistumiseen suhtautuvat poliitikot tuskin ilmoittautuvat yhtä todennäköisesti vapaaehtoisiksi osallistujiksi.

Edellä esitetyt tutkimustulokset osoittavat, että poliitikkojen osallistumisella voi olla useita myönteisiä vaikutuksia. Toisaalta osallistuminen puntaroivan kansalaiskeskustelun eri sovelluksiin asettaa poliitikot uudenlaisen tehtävän eteen. Kansalaiskeskustelut eroavat siitä, millaiseksi vaalidemokratiaan pohjautuvan poliittisen vaikuttamisen keinot ja tavoitteet perinteisesti käsitetään. Kansalaiskeskusteluihin osallistuvilta poliitikoilta tämä voi vaatia uudenlaisen asenteen omaksumista, jossa tavoitteena ei ole saada muita keskustelijoita poliitikon esittämien kantojen taakse, vaan kuulla erilaisia näkemyksiä ja löytää yhteisiä ja jaettuja näkökulmia sekä tavoitteita.

\section{TURKU KESKUSTELEE -KANSALAISPANEELI}

Turku keskustelee -kansalaispaneeli toteutettiin toukokuussa 2020. Kansalaispaneelissa 171 kuntalaista ja 21 valtuutettua keskustelivat siitä, miten Turun keskustan liikenne pitäisi tulevaisuudessa järjestää. Toteutimme kansalaispaneelin yhteistyössä Turun kaupungin kanssa. Kaupungin osallistuminen lisäsi paneelin merkittävyyttä, mutta asetti myös määrättyjä rajoitteita esimerkiksi aikatauluihin. Kaupungin tavoitteena oli kokeilla uudenlaista kuntalaisten osallistamisen mallia ja selvittää kuntalaisten puntaroivaan keskusteluun perustuva harkittu kanta keskustan liikennejärjestelyihin. Keskustelussa osallistujat ottivat kantaa kolmeen liikennesuunnittelun skenaarioon: Hidas muutos, Ripeä muutos ja Suuri muutos. Turun kaupunki 
tilasi skenaariot ulkopuoliselta konsulttitoimistolta, ja niitä käytetään pohjana kaupungin uuden yleiskaavan valmistelussa. Skenaarioiden keskeisiä tavoitteita olivat ilmastonmuutoksen torjunta, turvallisuus, liikenteen sujuvuus, sekä keskustan viihtyvyys. Skenaariot tarjosivat vaihtoehtoja sen suhteen, miten kunnianhimoisesti kaupungin keskustaa uudistetaan ilmastonmuutoksen torjumiseksi, ja ne erosivat toisistaan erityisesti sen suhteen, millaiseen käyttöön katutilaa keskustassa varataan. Kunnianhimoisin suuren muutoksen skenaario oli myös selkeästi kallein.

Keskustelut käytiin pienryhmissä verkossa, ja kukin pienryhmä keskusteli noin kolme tuntia. Yhteensä pientyhmäkeskusteluja järjestettiin 21. Pienryhmäkeskustelut käytiin joko suomeksi $(\mathrm{n}=19)$ tai ruotsiksi $(\mathrm{n}=2)$. Jokaista ryhmäkeskustelua fasilitoi puolueeton moderaattori. Jokaisessa ryhmässä oli keskustelumoderaattorin lisäksi tekninen moderaattori, joka auttoi tarvittaessa käyttäjiä. Työnjako moderaattorien välillä toimi hyvin, ja järjestelyn ansiosta keskustelut eivät häiriintyneet teknisten ongelmien vuoksi. Keskustelut oli tarkoitus alun perin käydä kasvokkain sitä varten varatuissa koulutiloissa Turun keskustassa, mutta covid-19-epidemian vuoksi siirryttiin verkkokeskusteluun. Keskustelut käytiin ilmaiseksi ladattavissa olevan Zoomohjelman välityksellä ja osallistuminen oli mahdollista tietokoneella tai mobiililaitteella. Osallistujille lähetettiin etukäteen Zoomin käyttöohje, heille järjestettiin ohjelman testausmahdollisuus sekä heitä ohjeistettiin tarpeen mukaan myös henkilökohtaisesti. Tällä pyrittiin siihen, ettei kukaan jättäisi osallistumatta puutteelliseksi kokemiensa digitaitojen vuoksi. Verkkokeskustelussa käytettiin ääniyhteyden lisäksi videokuvaa, jotta osallistujat näkivät toisensa ja moderaattorit. Verkon välityksellä käyty keskustelu oli sujuvaa ja muistutti kasvokkain käytävää keskustelua. Samankaltaisen havainnon on aiemmin tehnyt Kim Strandberg kollegoineen (2019) vertaillessa kasvokkain pienryhmissä käytyjä puntaroivia keskusteluja verkossa kameran välityksellä käytyihin vastaaviin keskusteluihin.

Kansalaispaneeliin osallistuvat kuntalaiset valittiin 15-79-vuotiaiden turkulaisten satunnaisotoksesta ( $n=12$ 000). Satunnaisotosta käytetään tyypillisesti puntaroivan demokratian käytännön toteutuksissa. Pyrkimyksenä on muodostaa mahdollisimman edustava ja siten moniääninen otos kansalaisista. Kutsu paneeliin lähetettiin postitse kaikille satunnaisotannalla valituille kuntalaisille. Kutsun yhteydessä kuntalaiset saivat myös kyselyn, jossa kartoitettiin heidän liikennejärjestelyjä koskevia mielipiteitään, poliittisia asenteitaan sekä taustamuuttujia. Kyselyn saaneista kuntalaisista 2463 palautti sen postitse tai vastasi siihen verkossa. Näin ollen kyselyn vastausprosentiksi muodostui 20,5\%.

Kyselyyn vastanneista kuntalaisista 370 ilmoitti olevansa kiinnostunut osallistumaan kansalaispaneeliin ja heistä 171 osallistui. Alkuperäinen tavoitteemme oli valita edustava otos osallistumishalukkuutensa ilmaisseista, mutta verkkoon siirtyminen ja pandemian puhkeaminen todennäköisesti verottivat halukkuutta siinä määrin, että otimme lopulta mukaan kaikki halukkaat. Myös yleiskaavan valmisteluprosessin aikataulu esti rekrytointiprosessin pidentämisen. Osallistujat edustivat suhteellisen hyvin erilaisia demografisia ryhmiä, vaikkakin paremmin toimeentulevien kaupunginosien asukkaat olivat hieman yliedustettuja. Lisäksi osallistujat olivat koulutetumpia kuin turkulaiset keskimäärin. Tätä voidaan pitää melko yleisenä ilmiönä puntaroivan kansalaiskeskusteluissa, sillä usein ne houkuttelevat korkeasti koulutettuja väestönosia (Karjalainen ja Rapeli 2015). Kuntalaisia kannustettiin osallistumaan paneeliin maksamalla jokaiselle osallistujalle 50 euron korvaus. 
Ennen paneelia kaikille ilmoittautuneille lähetettiin etukäteen postitse keskustelun säännöt sekä tietopaketti, jossa kuvattiin keskustan liikennejärjestelyjä koskevat vaihtoehtoiset skenaariot ja annettiin liikennesuunnittelua koskevaa taustatietoa. Tietopaketti laadittiin yhteistyössä tutkimusryhmän ja Turun kaupungin kanssa. Paketin tavoitteena oli esitellä skenaariot tasapuolisesti ja tarjota mahdollisimman tasapuolista taustatietoa liikennesuunnittelun keskeisistä teemoista. Osallistujia pyydettiin tutustumaan tietopakettiin ennen varsinaisia keskusteluja. $^{2}$

Kansalaispaneelia koskevan tutkimuksen tavoitteena oli verrata keskusteluja ja niiden vaikutuksia kahdenlaisissa ryhmissä. Jaoimme osallistujat satunnaisesti pienryhmiin: noin puolessa ryhmistä $(\mathrm{n}=11)$ oli mukana kaksi kaupunginvaltuutettua, toisessa puolessa valtuutettuja ei ollut $(n=10)$. Keskusteluihin osallistuvia kaupunginvaltuutettuja otettiin mukaan puolueryhmittäin siten, että heidän määränsä vastaisi valtuuston voimasuhteita. Kussakin pienryhmässä oli kaksi kaupunginvaltuutettua ja 7-11 kuntalaista lukuun ottamatta yhtä ryhmää, johon osallistui vain yksi valtuutettu. Kaupunginvaltuutetut arvottiin pienryhmiin valtuutettujen puoluetaustan mukaan, ja samassa pienryhmässä olevat valtuutetut edustivat aina eri puolueita. Keskusteluihin osallistui yhteensä 21 valtuutettua kuudesta puolueesta (kokoomus, perussuomalaiset, ruotsalainen kansanpuolue, sosiaalidemokraatit, vasemmistoliitto, vihreät) ${ }^{3}$. Kukin puolue valitsi itse omat edustajansa.

Keskusteluihin osallistuneet valtuutetut muodostivat suhteellisen heterogeenisen ryhmän, sillä joukossa oli ensimmäisen kauden valtuutettuja ja yksi varavaltuutettu sekä useamman kauden valtuustossa istuneita poliitikkoja. Myös iältään ja sukupuoleltaan valtuutettujen joukko oli suhteellisen monipuolinen. Paneeliin osallistuneista valtuutetuista 11 oli naisia ja 10 miehiä. Tämä vastaa hyvin valtuuston kokoonpanoa, jossa 67 valtuutetusta 33 on naisia ja 34 miehiä.

Kussakin pienryhmässä noudatettiin samaa menettelyä. Aluksi paneeliin osallistuvat kuntalaiset täyttivät lyhyen kyselyn, jossa mitattiin heidän yleistä politiikkatietämystään ja liikennejärjestelyjä koskevaa tietotasoaan. Tämän jälkeen heille esitettiin paneelia varten tehty esittelyvideo, jossa kaupunginjohtaja Minna Arve toivotti osallistujat tervetulleiksi ja Turun kaupungin kehittämispäällikkö Juha Jokela esitteli keskustan liikennesuunnittelun vaihtoehtoiset skenaariot ja kertoi liikenteen haasteista Turun keskustassa. Esittelyvideo pyrki samanlaiseen tasapuolisuuteen kuin osallistujille ennakolta lähetetty tietopaketti. Kussakin pienryhmässä keskustelua ohjasi moderaattori, jonka tehtävänä oli pitää huolta siitä, että keskustelu oli tasapuolista ja asiallista. Moderaattorin rooli oli pääsääntöisesti pysyä taustalla ja antaa keskustelun sujua vapaasti. Moderaattori puuttui keskusteluun vain, jos siinä esiintyi epäasiallista puhetta, vain osa keskustelijoista osallistui tai keskustelu tyrehtyi. Osallistujien tukena oli myös tekninen moderaattori, jonka tehtävänä oli auttaa osallistujia henkilökohtaisesti Zoom-sovellukseen liittyvien ongelmien ratkaisemisessa.

Pienryhmäkeskustelut alkoivat aina siten, että osallistujat (mukaan lukien kaupunginvaltuutetut) esittäytyivät ja kertoivat jonkin omasta mielestään tärkeän liikennejärjestelyihin liittyvän teeman. Tämän jälkeen osallistujat aloittivat keskustelun jostain esittäytymiskierroksen aikana esiin nostetusta teemasta. Mikäli osallistujat eivät aloittaneet keskustelua itse, moderaattori nosti keskustelun aiheeksi ensimmäisen osallistujan mainitseman teeman. Keskustelujen lopuksi osallistujat kävivät yhteenvetokierroksen, jossa jokainen osallistuja sai vapaasti kertoa omista tuntemuksistaan keskusteluihin liittyen. 
Pienryhmäkeskustelujen jälkeen paneeliin osallistuneet kuntalaiset vastasivat kyselyyn, jossa he pääsivät äänestämään kolmen skenaarion väliltä. Lisäksi kyselyssä kartoitettiin uudestaan liikennejärjestelyjä koskevia mielipiteitä, vastaajien tietotasoa, heidän omaa käsitystään tietojensa lisääntymisestä sekä kokemusta keskusteluista. Tarkastelemme tässä artikkelissa kahta viimeistä. Skenaarioita koskeva äänestystulos esiteltiin verkossa järjestetyssä julkisessa tiedotustilaisuudessa toukokuun lopulla 2020. Tilaisuudessa osallistujat saivat lisätietoa kansalaispaneelista ja heillä oli myös mahdollisuus esittää kysymyksiä järjestäjille. Paneelin jälkeen tehty kysely osoitti, että osallistujien mielipiteet muuttuivat keskustelujen johdosta entistä enemmän kevyttä liikennettä suosivaksi. Skenaariosta eniten kannatusta sai ripeän muutoksen skenaario, jota äänesti yli puolet keskusteluihin osallistuneista ${ }^{4}$. Laadimme paneelin keskeisistä tuloksista lausunnon, joka liitettiin osaksi yleiskaavaa koskevan valtuustokäsittelyn lausuntomateriaalia. Turun kaupunginvaltuusto tekee päätöksen kaupungin keskustan liikennejärjestelyiden jatkokehittämisestä osana uutta yleiskaavaa. Kaavaehdotus tuodaan kaupunginhallituksen hyväksyttäväksi vuoden 2021 aikana.

\section{AINEISTO JA TUTKIMUSMENETELMÄT}

Kansalaispaneeliin osallistuneet valtuutetut eivät täyttäneet kuntalaisille tarkoitettuja kyselylomakkeita, mutta kutsuimme kaikki osallistuneet valtuutetut tutkimushaastatteluun ja he täyttivät lyhyen kyselyn paneelin jälkeen. Osallistuneista 21 valtuutetusta 17 vastasi paneelin jälkeen tehtyyn kyselyyn, ja 11 valtuutettua osallistui 19.6.-27.6.2020 toteutettuihin haastatteluihin. Kyselyssä kartoitettiin erityisesti valtuutettujen syitä osallistua kansalaispaneeliin sekä selvitettiin, kuinka valtuutetut kokivat paneelin pienryhmäkeskustelut. Osallistumiskokemuksia koskevat kysymykset pohjautuvat vastaavissa tutkimuksissa aiemmin käytettyihin tutkimuspatteristoihin (Flinders ym. 2016). Kysymykset olivat pääosin samoja kuin kuntalaisille tehdyssä kyselyssä, mutta valtuutettuja ei pyydetty äänestämään kolmesta skenaariosta ${ }^{5}$. Valtuutettujen kyselyä analysoitaessa havaintoja heijastetaan edellä esiteltyyn kuntalaisille tehtyyn kyselyyn.

Haastatteluissa kartoitettiin valtuutettujen käsityksiä suorasta kansalaisosallistumisesta sekä heidän kokemuksiaan osallistumisesta Turku keskustelee -kansalaispaneeliin. Haastattelut toteutettiin etäyhteyden välityksellä videoneuvottelusovellusta käyttäen ja ne nauhoitettiin. Haastattelujen jälkeen nauhoitukset litteroitiin, jonka yhteydessä aineisto anonymisoitiin. Analyysi seurasi temaattista sisällönanalyysiä, jossa eri haastattelusitaatit koodattiin ja yhdistettiin erilaisten sitaattien sisältöä kuvaavien luokkien alle (Bryman 2012, 297). Yleisimmät teemat koskivat perusteita osallistumiselle, kokemuksia pienryhmäkeskusteluista sekä näkemyksiä keskusteluaiheen valinnasta ja yleisemmin hallinnon järjestämistä osallistumisen tavoista. Aineisto kävi läpi kaksi analyysikierrosta, jonka aikana käytettyä luokittelua tarkennettiin. Haastatteluihin viitataan tässä artikkelissa koodeilla V1-V11. 


\section{TURKULAISTEN VALTUUTETTUJEN KOKEMUKSET PUNTAROIVASTA KANSALAISPANEELISTA}

Valtuutetut ottivat kyselyssä kantaa osallistumisensa motivaatioon valitsemalla kyselyssä tarjotuista valmiista vastausvaihtoehdoista niin monta kuin halusivat. Valtuutetut esittivät tärkeimpinä syinä osallistumiselleen kiinnostuksen keskustan liikennejärjestelyihin sekä halun osallistua kaupungin päätöksentekoon, kuulla asukkaiden mielipiteitä ja olla mukana kehittämässä uusia suoran kansalaisosallistumisen muotoja (ks. Taulukko 1). Avoimissa vastauksissa valtuutetut mainitsivat muun muassa luottamustoimen sekä halun osallistua "ikään kuin pieneen 'torikokoukseen'". Haastatteluissa valtuutetut kertoivat ilmoittautuneensa kansalaispaneeliin, koska se tarjosi heille mahdollisuuden kuulla, mitä mieltä asukkaat ovat erilaisista kehitysvaihtoehdoista ja mitä skenaariota he pitävät kaikkein mielekkäimpänä (V3, V6, V8, V11). Lisäksi osa valtuutetuista kertoi osallistumisensa syyksi kiinnostuksen kansalaispaneelissa hyödynnettyä menetelmää kohtaan (V1, V2, V4, V5, V10). Monet haastatelluista suhtautuivat myönteisesti erilaisiin suoran kansalaisosallistumisen menetelmiin ja arvostivat sitä, että kansalaispaneeliin osallistumalla he pääsivät itse olemaan osallistujana tavallisten asukkaiden joukossa.

Taulukko 1. Valtuutettujen syyt osallistua kansalaispaneeliin, yhteensä 17 vastausta

\begin{tabular}{|l|c|}
\hline Olin kiinnostunut keskustan liikennejärjestelyistä. & 16 \\
\hline Halusin kuulla kaupunkilaisten mielipiteitä. & 15 \\
\hline Halusin osallistua Turun kaupungin poliittiseen päätöksentekoon. & 13 \\
\hline Halusin olla mukana kehittämässä uusia suoran kansalaisosallistumisen muotoja. & 13 \\
\hline Halusin edistää puolueeni tavoitteita. & 8 \\
\hline Halusin osallistua tieteelliseen tutkimukseen. & 7 \\
\hline Halusin tuoda esiin äänestäjieni toiveita. & 5 \\
\hline Kaipasin tekemistä arkipäiviksi. & 0 \\
\hline Muu, mikä? & 2 \\
\hline
\end{tabular}

Haastatteluissa kävi ilmi, että lähes kaikissa valtuustoryhmissä osallistujat valittiin kiinnostuksen mukaan. Vain yhdessä puolueessa oli merkkejä siitä, että valtuustoryhmän johto oli tarjonnut osallistumismahdollisuutta paneeliin ensisijaisesti sellaiselle valtuutetulle, jonka tiedettiin olevan ennestään perehtynyt käsiteltävään aiheeseen (V2). Vapaaehtoisten saaminen ei osoittautunut missään puolueessa erityisen vaikeaksi, vaikka osa haastatelluista valtuutetuista kertoi aikataulujen sovittamisen erityisesti päiväsaikaan järjestettyihin pienryhmäkeskusteluihin olleen haastavaa. 
Vaikka valtuutettujen edustamilla puolueilla oli hyvin erilaisia painotuksia muun muassa joukkoliikennettä sekä yksityisautoilua kohtaan, haastatellut kertoivat, etteivät he saaneet valtuustoryhmältään ohjausta siitä, mitä teemoja heidän tulisi keskusteluissa edistää. Vain yhden valtuustoryhmän edustaja kertoi, että heidän ryhmässään oli keskustelu etukäteen paneelissa käsiteltävistä teemoista sekä puolueen linjasta (V7). Haastatelluilla valtuutetuilla ei myöskään ollut vahvoja henkilökohtaisia agendoja, joita he olisivat halunneet keskusteluissa edistää.

Haastattelut kuitenkin osoittivat, että valtuutetut osallistuivat keskusteluihin hyvin erilaisissa rooleissa. Osa valtuutetuista pyrki hillitsemään omia puheenvuorojaan, antamaan muille tilaa ja olemaan korostetun neutraali (V3, V6, V9, V10). Yksi haastateltu puolestaan kertoi joutuneensa jopa osin tahtomattaan asiantuntijaksi, jolle muut osallistujat esittivät kysymyksiä ja jonka mielipiteitä haluttiin kuulla (V3). Yksi haastatelluista totesi myös joutuneensa korjaamaan muita osallistujia osin virheellisille tiedoille perustuvien väitteiden takia (V5). Tiedonantajan rooliin joutuminen oli haastateltujen mukaan osin luonnollista, koska valtuutetuilla oli muita osallistujia enemmän tietoa keskusteltavista kysymyksistä. He saattoivat esimerkiksi kertoa muille osallistujille, millä tavoin kysymyksistä oli jo aikaisemmin keskusteltu valtuustossa.

No sinänsä hyvä asia, et kansalaiset pääsee ilmaisemaan mielipiteensä ja ajatuksensa ja näkökantansa suoraan niille, jotka niitä päätöksiä tekee. Ja mun mielestä se oli sen takia hienoo, et -- sieltä tuli sit taas paluuviestinä ensikäden tietoo siitä, et miten niitä päätöksii tehdään ja missä mennään tiettyjen päätöksien osalta, mistä kaupunkilaiset halus saada enemmän tietoa. Niin se oli tavallaan kaksisuuntainen katu siltä osin, et me saatiin tietoa mut me pystyttiin myös sitä antamaan. (V2)

Haastatteluissa valtuutetut kertoivat suhtautuneensa kuntalaisten kanssa paneelin aikana käymiinsä keskusteluihin pääosin myönteisesti. Yhtä valtuutettua lukuun ottamatta (V7) kaikki kertoivat pitäneensä keskusteluja hyvähenkisinä ja myönteistä keskusteluilmapiiriä rakentavana. He kokivat, että kaikki saivat mahdollisuuden esittää oman mielipiteensä keskusteluissa, vaikka osa osallistujista oli luonnollisesti enemmän äänessä kuin muut. Myös kyselyssä lähes kaikki valtuutetut kertoivat olevansa samaa mieltä siitä, että osallistuminen oli miellyttävä kokemus (ks. Taulukko 2). 
Taulukko 2. Valtuutettujen ja kuntalaisten käsitykset kansalaispaneelista, täysin tai jokseenkin samaa mieltä olevien \%-osuus vastaajista; tilastollisesti merkitsevät erot $(\mathrm{p}<0.05)$ lihavoitu (keskiarvojen vertailu riippumattomien otosten $\mathrm{t}$-testillä)

\begin{tabular}{|c|c|c|c|c|}
\hline & & $\begin{array}{l}\text { Valtuutetut } \\
(n=17)\end{array}$ & $\begin{array}{l}\text { Kuntalais- } \\
\text { ryhmät } \\
(\mathrm{n}=87)\end{array}$ & $\begin{array}{l}\text { Seka- } \\
\text { ryhmät } \\
(n=84)\end{array}$ \\
\hline \multirow[t]{2}{*}{$\begin{array}{l}\text { Mielipiteen } \\
\text { muutos }\end{array}$} & $\begin{array}{l}\text { Turun keskustan liikennejärjestelyjä koskeva kantani muuttui kansalais- } \\
\text { paneelin aikana. }\end{array}$ & 0 & 32 & 38 \\
\hline & $\begin{array}{l}\text { Liikennejärjestelyjä koskeva mielipiteeni on nyt varmempi kuin ennen } \\
\text { keskustelua. }\end{array}$ & 71 & 86 & 86 \\
\hline \multirow[t]{2}{*}{$\begin{array}{l}\text { Tiedon } \\
\text { lisääntyminen }\end{array}$} & $\begin{array}{l}\text { Turun keskustan liikennejärjestelyjä koskevat tietoni lisääntyivät } \\
\text { kansalaispaneelin aikana. }\end{array}$ & 65 & 91 & 95 \\
\hline & $\begin{array}{l}\text { Keskustelu auttoi minua ymmärtämään erilaista elämää elävien turkulais- } \\
\text { ten arkea. }\end{array}$ & 88 & 95 & 92 \\
\hline \multirow{5}{*}{$\begin{array}{l}\text { Kokemus } \\
\text { keskusteluista }\end{array}$} & Osallistuminen pienryhmäkeskusteluun oli miellyttävä kokemus. & 88 & 100 & 99 \\
\hline & $\begin{array}{l}\text { Keskustelu osoitti, että myös omistani poikkeavat mielipiteet voivat olla } \\
\text { perusteltuja. }\end{array}$ & 76 & 93 & 95 \\
\hline & Pienryhmäkeskustelussa kunnioitettiin ja kuunneltiin toisten mielipiteitä. & 100 & 100 & 100 \\
\hline & Jotkut osallistujat hallitsivat liikaa keskustelua. & 18 & 9 & 13 \\
\hline & Ketään ei jätetty keskustelun ulkopuolelle. & 100 & 98 & 96 \\
\hline \multirow{3}{*}{$\begin{array}{l}\text { Vaikuttaminen } \\
\text { keskusteluihin }\end{array}$} & Osallistuin aktiivisesti keskusteluun pienryhmässäni. & 100 & 95 & 92 \\
\hline & Sain tuotua omat ajatukseni hyvin esille pienryhmässäni. & 100 & 98 & 94 \\
\hline & Muut osallistujat ottivat mielipiteeni huomioon keskustelun aikana. & 100 & 92 & 94 \\
\hline \multirow{3}{*}{$\begin{array}{l}\text { Moderoinnin ja } \\
\text { taustatietojen } \\
\text { tasapuolisuus }\end{array}$} & Pienryhmäkeskustelun moderaattori oli tasapuolinen. & 88 & 99 & 99 \\
\hline & Keskustelun tueksi saamani tietopaketti oli tasapuolinen. & 71 & 79 & 89 \\
\hline & Pienryhmäkeskustelussa katsomamme video oli tasapuolinen. & 71 & 82 & 86 \\
\hline Arvio tekniikasta & Netin välityksellä pystyi keskustelemaan mielestäni hyvin. & 100 & 94 & 94 \\
\hline \multirow{3}{*}{$\begin{array}{l}\text { Arvio } \\
\text { poliitikkojen } \\
\text { osallistumisesta }\end{array}$} & $\begin{array}{l}\text { Kaupunginvaltuutettujen läsnäolo pienryhmässä auttoi muita osallistujia } \\
\text { ymmärtämään aihetta. }\end{array}$ & - & - & 77 \\
\hline & $\begin{array}{l}\text { Keskustelu oli liian puoluepoliittista kaupunginvaltuutettujen läsnäolon } \\
\text { takia. }\end{array}$ & - & - & 7 \\
\hline & Olisi ollut parempi, että keskusteluun ei olisi osallistunut poliitikkoja. & - & - & 6 \\
\hline \multirow{2}{*}{$\begin{array}{l}\text { Yleisarvio } \\
\text { paneelista }\end{array}$} & Osallistuisin mielelläni uudelleen samantyyppiseen kansalaispaneeliin. & 88 & 95 & 99 \\
\hline & $\begin{array}{l}\text { Poliittisessa päätöksenteossa tulisi käyttää kansalaispaneelin tyyppisiä } \\
\text { kansalaisosallistumisen muotoja. }\end{array}$ & 88 & 95 & 99 \\
\hline
\end{tabular}


Taulukossa 2 esitämme valtuutettujen ja kuntalaisten vastaukset pienryhmäkeskustelujen jälkeen toteutettuun kyselyyn. Taulukossa sarakkeina ovat valtuutetut, pelkästään kuntalaisista koostuneiden ryhmien osallistujat (kuntalaisryhmät) ja kuntalaisista sekä valtuutetuista koostuneiden ryhmien kuntalaisosallistujat (sekaryhmät). Taulukossa esitetään väitteen kanssa samaa mieltä olleiden suhteelliset osuudet. Lisäksi taulukossa vertaillaan kuntalaisten vastausten keskiarvoja pelkistä kuntalaisista koostuvissa ryhmissä ja poliitikkoja sisältävissä ryhmissä riippumattomien otosten t-testillä.

Yksikään valtuutetuista ei ollut sitä mieltä, että hänen kantansa olisi muuttunut keskusteluiden aikana. Lähes kolme neljäsosaa heistä oli sitä mieltä, että paneelin jälkeen he olivat varmempia omasta kannastaan liikennejärjestelyitä koskien. Kuntalaisten keskuudesta puolestaan kolmasosa raportoi kantansa muuttuneen. Yli kaksi kolmasosaa valtuutetuista koki liikennejärjestelyjä koskevien tietojensa lisääntyneen paneelin aikana. Vastaavasti kuntalaisista yli 90 prosenttia koki tietojensa lisääntyneen.

Kuntalaisten kokemukset osallistumisesta olivat hyvin samansuuntaisia sekä niin sanotuissa kuntalaisryhmissä että sekaryhmissä. Kyselyn tulokset kertovat siitä, että valtuutettujen ja kuntalaisten yhteiset keskustelut sujuivat hyvin, eikä valtuutettujen osallistumisella ollut kielteisiä vaikutuksia keskustelun tasapuolisuuteen. Ainoat tilastollisesti merkitsevät erot ryhmien välillä liittyvät kokemukseen tiedon lisääntymisestä ja tietopaketin tasapuolisuudesta. Sekaryhmissä keskustelleet kuntalaiset kokivat tietojensa lisääntyneen hieman kuntalaisryhmäläisiä enemmän, mikä voi kertoa siitä, että valtuutetut selvensivät ja kertoivat kuntalaisille joitakin liikennejärjestelyihin liittyviä seikkoja. Saattaa olla, että valtuutetut olivat selventäneet myös tietopakettia, koska sekaryhmissä keskustelleet kokivat sen hieman useammin tasapuoliseksi kuin kuntalaisryhmissä keskustelleet.

Kyselyyn vastanneista valtuutetuista suurin osa oli täysin samaa mieltä siitä, että paneeli antoi heille paremman käsityksen tavallisten kuntalaisten arjesta. Haastatteluissa osa valtuutetuista kertoi, että paneelikeskustelu välitti heille lisää tietoa siitä, millaiset teemat ovat tärkeitä kuntalaisille ja mitkä päätökset saavat eniten tukea kuntalaisten keskuudessa (V2, V5, V8, V10, V11). Tämä on linjassa aiempien puntaroivia kansalaiskeskusteluja koskevien tutkimusten kanssa, joissa poliitikkojen on havaittu pitävän puntaroivaa kansalaiskeskustelua erityisesti tiedonkeruun menetelmänä (evidence-taking) eikä niinkään päätöksentekoon vaikuttamisen menetelmänä (Davidson ja Stark 2011; Hendriks 2016).

Se ei varsinaisesti ehkä viel vaikuttanu siihen näkemykseen, et miten se liikenne pitäis järjestää. Mut kyl se sitä ymmärryst lisäs ihmisten mielipiteist. Ja se on kuitenki se merkitsevin, koska heil ihmisil tätä tehdään. (V5)

Yksi valtuutetuista kertoi olleensa yllättynyt siitä, kuinka valveutuneita keskusteluihin osallistuneet kuntalaiset olivat monista keskustelujen aikana käsitellyistä kysymyksistä (V3). Osa oli myös yllättyneitä siitä, kuinka samanmielisiä keskustelijat olivat monista kysymyksistä (V3, V4, V9). Vaikka osallistujien mielipiteissä oli eroja, he pystyivät käymään keskusteluja toisiaan kunnioittaen ja kuunnellen. 
Mä olen yllättynyt sen keskustelun onnistumisesta. Siel oli selkeesti perussuomalaista ajattelua ja vihreetä ajattelua ja kuitenkin kaikki tuli toimeen aika hyvin yhdessä ilman, et siit olis tullu mitään kovin ilkeää keskustelua. Kaikki oli hyvin maltillisia kuitenkin. (V3)

Keskustelujen henki erosi haastateltujen mukaan heidän yleensä saamastaan kansalaispalautteesta, kuten vaalitorien kohtaamisista ja sähköpostilla tulevista yhteydenotoista. Valtuutettujen mukaan kuntalaisilta saatu palaute on tavallisesti sangen yksipuolista, ja sitä antavat kaikkein aktiivisimmat ja äänekkäimmät kansalaisryhmät (V1, V6). Kansalaispaneelin parhaimpana antina valtuutetut pitivätkin sitä, että se antoi heille perinteisiä vuorovaikutuskanavia monipuolisemman käsityksen kuntalaisten mielipiteistä.

Ja sen takia tää kansalaispaneeli oli must aika hyvä formaatti. Et siinä näitten kansalaisten piti aidosti perehtyä siihen aiheeseen mitä käsitellään. Ja aidosti osallistuu keskusteluun. Ettei se ollu vaan sellast ykspuolista valittamista tai kritiikkiä. Vaan myös kuunnella sitä, et millasii muita mielipiteitä siitä aiheesta voi olla. (V1)

Toisaalta kaikki haastatelluista valtuutetuista eivät olleet valmiita pitämään kansalaispaneelin osallistujia täysin varauksetta edustavana otoksena koko Turun kaupungin asukkaista (V5, V6). Osa valtuutetuista piti osallistujajoukkoa osittain vinoutuneena, ja uskoi sen edustavan vain valveutunutta kansaosaa, joka oli jo ennestään hyvin perehtynyt keskustelujen aiheisiin ja joilla oli selkeät mielipiteet muun muassa joukkoliikenteestä (V8, V9). Tästä syystä osa valtuutetuista epäili paneelin edustavuutta suhteessa turkulaisten mielipiteisiin yleisesti. Toisaalta kaikki valtuutetut pitivät paneelin aihetta hyvin valittuna ja kaikkia turkulaisia kiinnostavana. Valtuutettujen mukaan lähes kaikilla asukkailla on jonkinlainen kosketuspinta keskustan liikennejärjestelyihin. Liikenne on myös aihe, joka herättää asukkaissa voimakkaita mielipiteitä, minkä vuoksi valtuutetut pitivät asukkaiden kynnystä osallistua paneeliin suhteellisen matalana.

Valtuutetut myös pitivät kansalaispaneelin pienryhmien toimintatapaa mielekkäänä, koska se sai osallistujat pohtimaan omia kantojaan ja mahdollisesti muuttamaan niitä rakentavampaan suuntaan (V1). Yhtä lailla ennen paneelia osallistujille jaettu tietopaketti valotti kaupungin liikenneratkaisujen taustoja sekä eri skenaarioiden vaikutuksia (V2, V4, V10, V11). Osallistujilla oli siten parempi käsitys erilaisten päätösvaihtoehtojen taustoista ja seurauksista, ja he pystyivät puntaroimaan omia mielipiteitään saadun informaation ja keskustelujen pohjalta. Kyselyn mukaan valtuutetut uskoivat, että paneelin osallistujille annettu taustamateriaali sekä ennen paneelia esitetty video käsittelivät eri skenaarioita suhteellisen neutraalisti ja tasapuolisesti. Kuntalaisiin verrattuna valtuutetut suhtautuivat taustamateriaalin ja videon tasapuolisuuteen kuitenkin hieman kriittisemmin.

Valtuutettujen mukaan kaikki osallistujat osallistuivat pääsääntöisesti hyvin keskusteluihin, vaikka osa keskustelijoista olikin toisia vähemmän äänessä. Kyselyn mukaan valtuutetut eivät kokeneet, että jotkut osallistujista olisivat hallinneet keskustelua. Valtuutetut raportoivat osallistuneensa aktiivisesti pienryhmissä käytyihin keskusteluihin, eikä heillä ollut vaikeuksia saada omia ajatuksiaan esiin keskusteluiden aikana. Valtuutettujen arviot omasta kyvykkyydestään osallistua keskusteluihin ja saada puheenvuoroja keskustelujen aikana olivat hieman kuntalaisia myönteisemmät. 
Haastateltujen mukaan valtuutettujen kuntalaisia aktiivisempi rooli johtui osittain siitä, että valtuutetut olivat keskustelleet käsiteltävistä asioista jo aikaisemmin kaupunginvaltuustossa ja -hallituksessa ja heillä oli paljon ennen paneelia hankittua tietoa (V1, V3, V6, V8), minkä vuoksi heillä oli kuntalaisia paremmat valmiudet osallistua keskusteluun. Osa haastatelluista kertoi, että he pyrkivät tietoisesti pitämään roolinsa pienenä, jotta eivät "jyräisi" muita osallistujia keskustelussa (V9, V10).

Mä ehkä luulen, että minä ja se toinen [valtuutettu] osallistuja molemmat suhtautu siihen asiaan myös vähän niin, että ei se oo meidän tehtävämme mitenkään erityisemmin dominoida keskustelua, eikä olla tuomas niit omii mielipiteitään, vaan antaa sitä tilaa niille muille osallistujille. (V9)

Vaikka valtuutetut pitivät paneelin toimintatapaa ja keskusteluita onnistuneina, he olivat eri mieltä siitä, kuinka paljon paneeli ja sen jälkeen suoritettu äänestys lopulta vaikuttavat varsinaiseen päätöksentekoon. Osa valtuutetuista uskoi, että kaupungin johto on sitoutunut huomioimaan paneelin tuloksen osana keskustan liikennejärjestelyiden suunnittelua (V5, V10), kun taas osa epäili, että paneelin vaikutukset jäävät heikoiksi (V6, V7, V9, V11). Erityisesti mikäli äänestystulos osoittautuu päättäjien näkökulmasta täysin odotusten vastaiseksi, sen sivuuttaminen tai mitätöiminen oli osasta valtuutettuja mahdollista.

Se että miten se sitten johtaa siihen käytäntöön, niin se on sit toinen juttu ja sitäkin pitäis seurata, et miten se vaikutus todellisuudessa on. Et jos se sattuu olemaan esimerkiks meijän enemmistön näkemyksen vastaista tai kaupunginjohdon enemmistön näkemyksen vastaista, niin otetaanko se oikeasti vastaan, vai kierretäänkö sitä sitten jollain kauniilla sanoilla. Et hauska nähdä. (V3)

Valtuutetut olivat erimielisiä myös siitä, kuinka onnistunut paneelin ajoitus oli. Osa oli sitä mieltä, että paneeliin osallistuneilla kuntalaisilla oli vielä aito mahdollisuus vaikuttaa tuleviin päätöksiin. Osa taas piti paneelin ajankohtaa väistämättä liian myöhäisenä, sillä monet päätöksen reunaehdot oli jo lyöty lukkoon, minkä vuoksi paneelilla ei enää ollut mahdollisuutta vaikuttaa moniin liikennejärjestelyiden kannalta tärkeisiin kysymyksiin. Yksi valtuutetuista uskoi, että paneelin varsinaisena tarkoituksena ei ollutkaan antaa asukkaille todellista mahdollisuutta osallistua päätöksentekoon, vaan paneelilla pyrittiin legitimoimaan jo tehtyjä päätöksiä.

No joo siis mä olen vaan itse ollu vähän harmissani kun selvästi meillä tämä ripeä vaihtoehto on työn alla, elikkä sitä on tyrkytetty jo etukäteen aika voimakkaasti ja se on selvästi yleiskaavan pohjana. Ja sitä on valmisteltu ennen kun on sanottu et kansalaispaneeli otetaan vahvasti huomioon ja se antaa osviittaa. Ja siit huolimatta työpohja on ollu selkeesti joku näistä ja mä en oo oikein itte tykänny siitä. (V3)

Haastatteluissa valtuutetut pitivät omaa rooliaan suhteessa paneelin vaikuttavuuteen melko merkittävänä. Valtuutetuilla on mahdollisuus vaikuttaa paneelin tulosten eteenpäin viemiseen esimerkiksi pitämällä paneelin tuloksia esillä valtuustokäsittelyssä ja siten estämällä niiden 
hautautumista muun taustamateriaalin alle. Erään valtuutetun mukaan kuntalaisten käsityksiin vetoaminen voi antaa valtuutetuille "vipuvartta" keskusteluissa keskustan liikennejärjestelyistä (V11). Monet valtuutetuista kertoivatkin jo keskustelleensa muiden valtuustoryhmänsä jäsenten kanssa keskustelujen sisällöistä tuoreeltaan paneelin jälkeen (V2, V4, V10). Monet myös kertoivat aikovansa nostaa keskusteluja esiin ryhmässään, valtuuston kokouksissa ja tiedotusvälineissä esimerkiksi kirjoittamalla mielipidekirjoituksia paikallisiin sanomalehtiin (V1, V3, V4, V5, V6, V7, V11).

Valtuutettujen mukaan heidän valmiuteensa nostaa kansalaispaneelin tuloksia esiin valtuustoryhmän sisällä ja valtuustossa vaikuttaa se, kuinka selkeä paneelin lopputulos on. Mitä selkeämpi äänestystulos on, sitä helpompi valtuutettujen on vedota siihen ja sitä vaikeampi äänestystulosta on täysin sivuuttaa.

Ehkä siinä tapauksessa vois vaikuttaa, jos sieltä tulis joku tosi selkee kanta tuloksena, et kansa on tätä mieltä. Jos miettii valtuustokeskustelun tasoo ja sitä argumentointii, mitä siel tehdään, ehkä jollain sellasella statementilla vois olla ihan merkittäväkin vaikutus siihen, että pystyy perustelemaan, että no toi, mitä sä nyt ehdotat, on täysin vastakkaista sen kans, mitä kansalaispaneelin osallistuja on sanonut. Mut riippuu tosiaan ihan siitä, et miten tulokset esitellään. (V10)

Paneelin vaikuttavuudessa keskeistä on valtuutettujen mukaan myös se, miten paneelin prosessista ja tuloksista raportoidaan päättäjille ja laajemmalle yleisölle. Mikäli päättäjät kokevat, että paneelin äänestystulos edustaa kuntalaisten harkittuja näkemyksiä keskustan liikennejärjestelyiden kehittämisestä, he ovat myös valmiimpia antamaan tukensa äänestyksessä voittaneelle ehdotukselle. Tämä luo vaatimuksia myös paneelin järjestämisestä vastanneille tutkijoille, jotta päättäjillä olisi selkeä käsitys siitä, millä periaatteilla paneelin osallistujat on rekrytoitu ja miten he ovat mielipiteensä muodostaneet.

Ja must tuntuu, et ehkä se pitää kans päättäjille selittää aika selkeesti, että mikä on tällanen satunnaisotanta ja mitä on deliberatiivinen demokratia ja mitä on nää keinot. Miten niitä käytetään, että ne on ihan edustavia ja kattavia. Ja nyt on tultu tämmöseen tulokseen sitte tätä kautta. (V4)

Mainituista varauksista huolimatta suurin osa valtuutetuista suhtautui myönteisesti kansalaispaneelin tyyppisen suoran kansalaisosallistumisen hyödyntämiseen jatkossakin. Myös haastatteluissa valtuutetut suhtautuivat myönteisesti puntaroivan keskustelun menetelmien lisäämiseen (V2, V6, V8, V11). Yksi haastateltavista piti paneelin erityisenä antina sitä, että se haastaa kaupungin perinteisiä päätöksentekoprosesseja, joissa päätöksenteko karkaa tavallisten kuntalaisten ulottumattomiin.

Ennen kaikkea Turun kaupungille se on erittäin [naurahtaa] tärkeää. Mehän ollaan surullisen kuuluisia siitä, miten tavallaan kuppikuntaistunutta ja hyvävelijärjestelmän pahoinpitelemää tää Turun päätöksenteko on ollu vuosikymmeniä. Niin ennen kaikkea Turun kaltaisessa kaupungissa tällainen kansalaiskeskustelu on raikas tuulahdus siihen ummehtuneeseen kabinetti-ilmapiiriin, mitä täällä on harjoitettu. (V2) 
Valtuutetut ja kuntalaiset olivat myös valmiita osallistumaan uudelleen vastaavaan kansalaispaneeliin. Haastatteluissa osa valtuutetuista suhtautui myönteisesti ajatukseen, että poliitikot osallistuisivat jatkossakin puntaroiviin kansalaispaneeleihin (V2, V6, V11). Yhden valtuutetun mukaan osallistuminen puntaroiviin kansalaispaneeleihin tai -raateihin tulisi jopa tehdä pakolliseksi jokaiselle valtuutetulle siten, että kukin valtuutettu osallistuisi ainakin yhteen kansalaiskeskusteluun valtuustokauden aikana.

Mä tekisin sen pakolliseks kaikille valtuutetuille, koska ei oo yhtään valtuutettua, joka ilman turkulaisia istuis siellä. Mun mielestä tämmösiä pitäis olla paljon enemmän ja jokaisella valtuutetulla pitäis olla minimimäärä, mihin on pakko osallistua. Ja kuitenkin me saadaan myös palkkiota meijän tehtävistä, niin mun mielestä se ei oo kauheen paljon vaadittu, että jos siellä valtuustossa istuu ja nauttii kokouspalkkioita ja muita, et myös kuuntelee niitä ihmisiä, jotka on sut sinne äänestäny. (V11)

Haastattelut osoittavat, että valtuutettujen joukosta löytyy tukea ajatukselle, että puntaroivat kansalaiskeskustelut tuotaisiin tiiviimmin osaksi kaupungin päätöksentekoprosesseja. Myös valtuutetut olivat itse kiinnostuneita ottamaan osaa keskusteluihin, mikäli niitä järjestettäisiin vastaisuudessa. Viimeisessä sitaatissa nostetaan esiin jopa ajatus, että osallistuminen kansalaiskeskusteluihin sisällytettäisiin valtuutettujen normaaliin toimenkuvaan perinteisen edustuksellisuudelle perustuvan toiminnan rinnalle vahvistamaan valtuutettujen ja kuntalaisten yhteyttä.

\section{JOHTOPÄÄTÖKSET}

Tutkimme Turku keskustelee -kansalaispaneeliin osallistuneiden kaupunginvaltuutettujen kokemuksia puntaroivasta kansalaiskeskustelusta. Analyysi perustui kansalaispaneeliin osallistuneiden valtuutettujen haastatteluihin ja heille tehtyyn kyselyyn sekä kansalaispaneeliin osallistuneille kuntalaisille suunnattuun kyselyyn. Saadut tulokset lisäävät tietoa siitä, millaisena vaikuttamisen välineenä poliitikot kokevat puntaroivat kansalaiskeskustelut. Tutkimustuloksillamme on merkitystä kuntademokratian edistämisen kannalta. Ne auttavat ymmärtämään, voiko poliitikkojen osallistuminen puntaroivaan kansalaiskeskusteluun vahvistaa vaikuttavuutta päätöksentekoon vai johtaako se pelkästään keskusteluiden muuttumiseen puoluepoliittisen toiminnan jatkeeksi, jossa eri puolueiden edustajat pyrkivät tuomaan esiin ja edistämään puolueidensa tavoitteita.

Tutkimuksemme osoittaa, että valtuutetut eivät osallistuneet kansalaispaneeliin ensisijaisesti edistääkseen puolueensa tai äänestäjiensä tavoitteita. Sen sijaan he osallistuivat kuullakseen kuntalaisten mielipiteitä liikennejärjestelyistä sekä ollakseen mukana kehittämässä uusia suoran kansalaisosallistumisen malleja. Myös kiinnostus suoran kansalaisosallistumisen muotoja kohtaan saattoi motivoida valtuutettuja osallistumaan puntaroiviin kansalaiskeskusteluihin. Esimerkiksi Irlannin kansalaiskokoukseen osallistuneilla poliitikoilla kiinnostus suoraa kansalaisosallistumista kohtaan oli jo valmiiksi korkea (Farrell ym. 2020, 14). 
Haastattelujemme perusteella vaikutti siltä, että valtuutetut saivat haluamaansa tietoa kuntalaisten mielipiteistä: keskustelu antoi valtuutetuille tavallisia kansalaiskohtaamisia kokonaisvaltaisemman kuvan siitä, mitkä asiat ovat kuntalaisten mielestä tärkeitä ja millaisille päätöksille he antavat tukensa. Näin kansalaispaneeli antoi valtuutetuille arvokasta ruohonjuuritason tietoa siitä, millaisia liikenneratkaisuja kuntalaiset kannattavat, millaisia liikkumismuotoja he olisivat valmiita käyttämään ja miten kuntalaiset arvottavat eri vaihtoehtoihin liittyviä kustannuksia.

Kyselymme kuitenkin osoitti, ettei osallistuminen paneeliin muuttanut valtuutettujen kantoja keskustan liikennejärjestelyistä. Tämä voi kieliä siitä, että valtuutettujen näkemykset vastasivat kuntalaisten keskusteluissa esittämiä kantoja, joten erimielisyyksiä ei päässyt syntymään eikä poliitikoilla ollut tarvetta muuttaa ennakkokäsityksiään. Toisaalta aikaisemmissa tutkimuksissa on esitetty, että kansalaisten mielipiteillä voi olla hyvin vähän vaikutusta poliitikkoihin sellaisissa kysymyksissä, joihin poliitikot ovat jo muodostaneet kantansa (Karlsson 2012).

Vaikka kansalaispaneelilla ei ollutkaan suurta vaikutusta valtuutettujen kantoihin keskustelujen sisältökysymyksissä, paneeliin osallistumisella voi olla vaikutusta valtuutettujen puntaroivia kansalaispaneeleja koskeviin käsityksiin sekä laajemmin suoraan kansalaisosallistumiseen. Saimme näyttöä siitä, että keskustelut paransivat valtuutettujen käsitystä kuntalaisten keskustelutaidoista. Kansalaispaneelia ennen saatu informaatio lisäsi kuntalaisten kykyä keskustella tietoperusteisesti ja pohjata argumenttinsa saamansa tiedon varaan, mikä saattoi osaltaan kuroa umpeen kuntalaisten ja valtuutettujen välistä eroa kyvyssä osallistua keskusteluun.

Valtuutetut pitivät pääsääntöisesti kansalaispaneelin menettelyä onnistuneena ja suosittivat vastaavien osallistumismuotojen käyttöä laajemminkin täydentämään kuntademokratiaa. Yksi haastatelluista piti kokemusta niin avartavana, että suositteli kansalaispaneeliin osallistumisen tekemistä pakolliseksi kaikille valtuutetuille. Tästä ei kuitenkaan voida tehdä suoraan johtopäätöstä siitä, että kokemus paneelista olisi vaikuttanut valtuutettujen näkemyksiin, sillä valtuutettujen näkemyksiä ei kartoitettu ennen paneelia. Koska valtuutetut osallistuivat vapaaehtoisesti paneeliin, suhtautuivat he todennäköisesti kuntalaisten suoraan osallistumiseen lähtökohtaisesti myönteisesti.

Toisaalta poliitikkojen suhtautuminen kansalaiskeskusteluihin voi kuitenkin olla hyvin kontekstisidonnaista (Hendriks 2006). Poliitikot voivat suhtautua myönteisemmin sellaisiin kansalaiskeskusteluihin, jotka eivät suoraan haasta heidän päätösvaltaansa (Koskimaa ja Rapeli 2020). Tuki kansalaiskeskusteluille voi olla vahvempaa sellaisten ryhmien keskuudessa, jotka eivät tällä hetkellä ole vallassa ja jotka näkevät, että osallistumalla kansalaiskeskusteluihin he voivat tuoda esiin ja edistää omia näkökantojaan. Tässä tutkimuksessa emme kuitenkaan ole ottaneet lähempään tarkasteluun paneelin järjestämiseen johtaneita olosuhteita tai eri valtuustoryhmien asennoitumista paneelissa käsiteltyihin teemoihin. Emme myöskään tarkastele, kuinka paneeliin tulokset otetaan huomioon varsinaisessa päätöksenteossa tai kuinka valtuustoryhmät tai yksittäiset valtuutetut tuovat niitä esiin valtuustossa tai muita kanavia pitkin.

Haastatteluissa valtuutetut myös esittivät kriittisiä huomioita, joita kannattaisi pohtia, kun kansalaispaneeleja järjestetään jatkossa. Yksi haastatelluista piti kansalaispaneelin ajoitusta huonona, koska hänen mukaansa käsitellyn asian keskeisistä suuntaviivoista oli jo siinä vaiheessa päätetty. Onkin tärkeää, että kansalaiset saavat osallistua päätöksentekoon siinä vaiheessa, kun asioihin voi aidosti vaikuttaa, jottei osallistumisesta tule jo tehtyjen päätösten legitimointikanavaa. Jotkut haastatellut myös epäilivät kansalaispaneelin vaikutusta kaupungin 
päätöksentekoon, etenkin jos paneelin lopputulos ei ole selkeä. Olisikin tärkeää, että kansalaisten osallistamiseen ja osallistamismenettelyjen tulosten käsittelyyn liittyy selkeät ja vakiintuneet menettelyt, jotka ohjaavat demokraattisten innovaatioiden lopputulosten käyttöä poliittisessa prosessissa.

Osa haastatelluista valtuutetuista myös kantoi huolta paneeliin osallistuneiden kuntalaisten edustavuudesta suhteessa koko väestöön. Onkin totta, että Turku keskustelee -kansalaispaneelin osallistujat olivat keskimäärin korkeammin koulutettuja kuin väestö keskimäärin. Osallistujia oli kuitenkin useista väestöryhmistä, ja paneeli oli aidosti moniääninen. Kansalaispaneelien järjestäjien tulisi silti varata riittävästi aikaa ja resursseja osallistujien rekrytointiin, jotta eri väestöryhmien edustus voidaan taata. Kaikki valtuutettujen esiin nostamat kriittiset huomiot antavat tärkeitä eväitä puntaroivien kansalaispaneelien suunnitteluun ja toteutukseen tulevaisuudessa ja viittaavat siihen, että puntaroivien kansalaispaneelien systemaattinen käyttö määrätyissä politiikkaprosesseissa vakiintuneiden käytäntöjen mukaisesti tuo parhaat lopputulokset.

Tutkimuksemme osoittaa, että puntaroivilla kansalaispaneeleilla ja muilla puntaroivan kansalaiskeskustelun muodoilla voi olla vaalidemokratiaa täydentävä vaikutus. Ne voivat rikastaa päätöksenteon tietopohjaa sekä vahvistaa poliitikkojen uskoa kansalaisten kykyihin osallistua päätöksentekoon ja muodostaa valistuneita mielipiteitä.

Demokratiainnovaatioiden tutkimuksessa huomio kohdistuu usein siihen, miten perinteisiä demokraattisia instituutioita pitäisi muokata, jotta ne pystyisivät ottamaan paremmin vastaan kansalaisten suoran palautteen. Poliitikkojen osallistuminen puntaroiviin kansalaiskeskusteluihin ei edellytä suuria muutoksia vaalidemokratiaan perustuviin päätöksentekoprosesseihin. Pikemminkin tulostemme pohjalta voidaan esittää, että osallistuminen tasavertaiseen puntarointiin kansalaisten kanssa tarjoaa hyödyllisiä eväitä perinteisten luottamustoimien hoitamiselle ja voi näin ollen osaltaan vahvistaa vaalidemokratiaa.

Lisäksi poliitikkojen osallistuminen puntaroiviin kansalaiskeskusteluihin voi vahvistaa puntaroivan demokratian mallien sekä vaalidemokratian periaatteille perustuvien päätöksentekoprosessien kytköstä. Poliitikot voivat toimia tärkeinä viestinviejinä, jotka vievät kansalaispaneelin tuloksia osaksi päätöksentekoa nostamalla niitä osaksi päätöksistä käytävää keskustelua, tai omaksumalla joitain asioista osaksi omaa tai edustamansa puolueen poliittista agendaa. Toisaalta poliitikkojen aktiivinen rooli viestinviejinä ei rajoitu pelkästään yksisuuntaiselle tiedonvälitykselle, vaan mahdollistaa myös tiedon välittämisen poliitikoilta kansalaisille. Osallistumalla puntaroivaan kansalaiskeskusteluun, poliitikot voivat välittää kansalaisille tietoa valtuuston "vallan kabineteista" ja tuoda päätöksentekoa näin lähemmäksi tavallisia kansalaisia. Näin puntaroivat kansalaispaneelit voivat myös kuroa umpeen kuilua kansalaisten ja poliitikkojen välillä.

Pohdimme vielä lopuksi, millaisia kansalaispaneelien järjestämistä koskevia politiikkasuosituksia voisimme antaa Turku keskustelee -kokemuksemme pohjalta. Aluksi toteamme, että laaja tutkimusnäyttö puoltaa poliittisen järjestelmän täydentämistä puntaroivilla kansalaiskeskusteluilla. On kuitenkin tärkeää, että kansalaisia kuullaan aidosti, eikä heitä osallisteta legitimoimaan jo tehtyjä päätöksi tai oteta mukaan muuten poliittisten päättäjien kannalta otollisessa vaiheessa päätöksentekoprosessia. Jotta tässä tavoitteessa onnistuttaisiin, voisi olla hyvä, että kuntademokratiaa täydennettäisiin koko valtuustokauden mittaisella pysyvällä kansalaispaneelilla, joka muodostetaan satunnaisotannan perusteella. Paneelin tehtävät ja rooli suhteessa valtuustoon pitäisi olla selkeästi määritelty. Tämän tyyppinen pysyvä kansalaispaneeli olisi 
institutionaalinen osa kunnanvaltuuston työskentelyä, mutta päätösvalta säilyisi silti kunnanvaltuustolla. Kunnanvaltuusto ja -hallitus sekä lautakunnat voisivat konsultoida kansalaispaneelia silloin, kun on tarpeen saada selville kuntalaisten harkittu mielipide jostain asiakysymyksestä tai -kokonaisuudesta. Kansalaispaneelia voidaan käyttää myös arvioimaan ja tuottamaan puolueetonta tietoa tai suosituksia muille kuntalaisille. Kansalaispaneelin suositukset voivat toimia oman äänestyspäätöksen ja mielipiteen muodostamisen tukena muille kuntalaisille esimerkiksi kunnallisen kansanäänestyksen edellä (ks. Warren ja Gastil 2015; Leino ym. 2019).

Tosin olisi hyvä sopia etukäteen myös siitä, missä vaiheessa päätöksentekoprosessia kansalaispaneelia kuullaan. Jotta kansalaispaneelia käytettäisiin kuntalaisia laajasti koskettavista ja merkittävistä aiheista kuntalaisille voitaisiin myöntää aloiteoikeus kansalaispaneelin järjestämiseksi. Tietty enemmistö kansalaispaneelin jäsenistä tai kuntalaisaloitelainsäädäntöä vastaava prosenttiosuus kuntalaisista voisi esimerkiksi vaatia kansalaispaneelin työskentelyn käynnistämistä jostakin kunnan toimivaltaan kuuluvasta aiheesta.

Toinen seikka, johon haluamme kiinnittää huomiota, on kansalaispaneelin osallistujien rekrytointiprosessi. Paneelin onnistumisen kannalta on tärkeää, että sen kokoonpano on riittävän edustava. Paneelin jäsenet tulisi valita kiintiöidyllä satunnaisotoksella niin, että he edustavat kuntalaisia monipuolisesti. Kiintiöitä voisivat olla esimerkiksi sukupuoli, ikä, koulutus ja asuinpaikka. Moniäänisyysvaatimuksen mukaisesti paneelin tulisi olla kooltaan tarpeeksi iso, esimerkiksi kolme kertaa kunnanvaltuuston kokoinen. Rekrytointiprosessiin pitää varata riittävästi resursseja, koska moniäänisen paneelin kokoaminen saattaa olla haastavaa. Kansalaispaneeleihin valikoituu herkästi yliedustus kansalaisista, jotka ovat muutenkin aktiivisia passiivisempien kansanryhmien jäädessä pois. Satunnaisotanta kuitenkin takaa sen, että kullakin kuntalaisella on yhtä suuri todennäköisyys tulla valituksi eikä kampanjoinnilla tai resurssoinnilla voi vaikuttaa valituksi tulemiseen.

Turku keskustelee -kansalaispaneelin kokemukset poliitikkojen mukanaolosta olivat pääosin myönteisiä. Suunnilleen samaa menettelyä käyttäen kansalaispaneeleita voisi järjestää myös jatkossa. Kansalaispaneelille voisi laatia työjärjestyksen, jonka mukaan paneelin osallistujat saisivat aluksi tietoa, keskustelisivat sen jälkeen satunnaisesti jaetuissa pienryhmissä, pohtisivat kysymysten esittämistä asiantuntijoille ja poliitikoille, kokoontuisivat täysistuntoon kuulemaan edellä mainittuja tahoja ja kokoontuisivat uudestaan pienryhmiin. Jälkimmäisessä pienryhmävaiheessa poliitikot voisivat osallistua keskusteluun "kaksisuuntaisen kadun" luomiseksi. Näin vaalidemokratian yhteys kuntalaisiin vahvistuisi uudella tavalla ja demokraattinen päätöksenteko voisi olla responsiivisempaa suhteessa harkittuun kansalaismielipiteeseen.

\section{TUTKIMUKSEN RAHOITUS}

Tutkimusta rahoittivat Åbo Akademin huippututkimusyksikkö FutuDem, Turun kaupunkitutkimusohjelma sekä strategisen tutkimuksen neuvosto, joka toimii Suomen Akatemian yhteydessä (päätösnumerot 312671/326662). 


\section{KIITOKSET}

Kiitämme Turun kaupungin edustajia, erityisesti Minna Arvea, Riitta Birkstedtiä, Juha Jokelaa ja Anri Niskalaa hyvästä yhteistyöstä Turku keskustelee -kansalaispaneelin suunnittelussa ja toteutuksessa, Sampo Ruoppilaa hankkeen tukemisesta sekä Maija Setälää alkuperäisestä ideasta tutkia poliitikkojen osallistumista.

\section{VIITTEET}

1. Koska Suomessa ei ole vakiintuneita käsitteitä erilaisille puntaroivan demokratian malleille, käytämme nimitystä puntaroiva kansalaiskeskustelu yleisterminä puntaroivan demokratian ihanteiden mukaisesti järjestetyille, keskusteluun pohjautuville osallistumismuodoille (ks. Aarninsalo ym. 2020). Nimesimme Turku keskustelee -kansalaispaneelin paneeliksi sen suhteellisen suuren osallistujamäärän vuoksi. Nimikettä kansalaisraati on käytetty lähinnä prosesseissa, joissa osallistujajoukko on ollut huomattavasti pienempi (Leino ym. 2019).

2. Kansalaispaneelin tietopaketti on saatavilla artikkelin kirjoittajilta pyynnöstä.

3. Keskustan valtuustoryhmästä ei ilmoittautunut yhtään valtuutettua paneeliin.

4. Katso tarkemmin: https://www.abo.fi/turkukeskustelee/.

5. Kansalaispaneelin kyselyt ovat saatavilla artikkelin kirjoittajilta pyynnöstä.

\section{LÄHTEET}

Aarninsalo, Lyydia, Jäske, Maija, Kulha, Katariina, Leino, Mikko ja Setälä, Maija. 2020. Moniäänistä ja perusteltua päätöksentekoa. Puntaroivat kansalaiskeskustelut poliittisten kiistakysymysten ratkaisussa. Palo-hankkeen julkaisuja. https://paloresearch.fi/ratkaisut/politiikkasuositukset/. Viitattu 3.2.2021.

Bengtsson, Åsa ja Wass, Hanna. 2011. The representative roles of MPs: A citizen perspective. Scandinavian Political Studies 34:2, 143-167. https://doi.org/10.1111/j.1467-9477.2011.00267.x

Bohman, James. 1998. The coming age of deliberative democracy. Journal of Political Philosophy 6:4, 400-425.

Boswell, John, Hendriks, Carolyn M. ja Ercan, Selen A. 2016. Message received? Examining transmission in deliberative systems. Critical Policy Studies 10:3, 263-283.

https://doi.org/10.1080/19460171.2016.1188712

Bryman, Alan. 2012. Social Research Methods. Oxford: Oxford University Press.

Bächtiger, André ja Goldberg, Saskia. 2020. Towards a more robust, but limited and contingent defence of the political uses of deliberative minipublics. Journal of Deliberative Democracy 16:2, 33-42. https://doi.org/10.16997/jdd.390

Chambers, Simone. 2009. Rhetoric and the public sphere: Has deliberative democracy abandoned mass democracy? Political Theory 37:3, 323-350. https://doi.org/10.1177/0090591709332336

Curato, Nicole ja Böker, Marit. 2016. Linking mini-publics to the deliberative system: A research agenda. 
Policy Sciences 49:2, 173-190. https://doi.org/10.1007/s11077-015-9238-5

Davidson, Stewart ja Stark, Alastair. 2011. Institutionalising public deliberation: Insights from the Scottish Parliament. British Politics 6:2, 155-186. https://doi.org/10.1057/bp.2011.3

Dryzek, John S. 2000. Deliberative democracy and beyond: Liberals, critics, contestations. Oxford: Oxford University Press.

Dryzek, John S. 2001. Legitimacy and economy in deliberative democracy. Political Theory 29:5, 651669. https://doi.org/10.1177/0090591701029005003

Elstub, Stephen. 2014. Mini-publics: issues and cases. Teoksessa Stephen Elstub ja Peter McLaverty (toim.), Deliberative Democracy: Issues and Cases. Edinburgh: Edinburgh University Press, 166-188.

Esaiasson, Peter. 2000. How members of parliament define their task. Teoksessa Peter Esaisson ja Knut Heidar (toim.), Beyond westminster and congress: The nordic experience. Columbus: Ohio State University Press, 51-82.

Farrell, David M. 2014. Deliberative democracy, Irish style. Inroads 1:34, 110-117.

Farrell, David M., Suiter, Jane, Harris, Clodagh ja Cunningham, Kevin. 2020. The effects of mixed membership in a deliberative forum: The Irish constitutional convention of 2012-2014. Political Studies 68:1, 54-73. https://doi.org/10.1177\%2F0032321719830936

Fishkin, James S. 1991. Democracy and deliberation. Yale: Yale University Press.

Fishkin, James S. 2009. When the people speak. Deliberative democracy and public consultation. Oxford: Oxford University Press.

Flinders, Matthew, Ghose, Katie, Jennings, Will, Molloy, Edward, Prosser, Brenton, Renwick, Alan, Smith, Graham ja Spada, Paolo. 2016. Democracy matters: Lessons from the 2015 citizens' assemblies on English devolution. https://citizensassembly.co.uk/wp-content/uploads/2016/04/Democracy-Matters-2015Citizens-Assemblies-Report.pdf. Viitattu 3.2.2021.

Fournier, Patrick, Kolk, Henk van der, Carty, R. Kenneth, Blais, André ja Rose, Jonathan. 2011. When citizens decide: Lessons from citizen assemblies on electoral reform. Oxford: Oxford University Press. https://doi.org/10.1093/acprof:oso/9780199567843.001.0001

Fung, Archon. 2006. Varieties of participation in complex governance. Public Administration Review 66:1, 66-75. https://doi.org/10.1111/j.1540-6210.2006.00667.x

Gastil, John, Knobloch, Katherine R., Reedy, Justin, Henkels, Mark ja Cramer, Katherine. 2018. Assessing the electoral impact of the 2010 Oregon Citizens' Initiative Review. American Politics Research 46:3, 534-563. https://doi.org/10.1177/1532673X17715620

Grönlund, Kimmo, Bächtiger, André ja Setälä, Maija. (toim.). 2014. Deliberative mini-publics: Involving citizens in the democratic process. Colchester: ECPR Press.

Grönlund, Kimmo, Herne, Kaisa ja Setälä, Maija. 2015. Does enclave deliberation polarize opinions? Political Behavior 37:4, 995-1020. https://doi.org/10.1007/s11109-015-9304-x

Grönlund, Kimmo, Setälä, Maija ja Herne, Kaisa. 2010. Deliberation and civic virtue: Lessons from a citizen deliberation experiment. European Political Science Review 2:1, 95-117. https://doi.org/10.1017/S1755773909990245

Gutmann, Amy ja Thompson, Dennis. 1996. Democracy and disagreement. Cambridge: Belknap Press of Harvard University Press.

Habermas, Jürgen. 1975. Legitimation crisis. Cambridge: Beacon.

Habermas, Jürgen. 2006. Political communication in media society: Does democracy still enjoy an epistemic dimension? The impact of normative theory on empirical research. Communication Theory 
$16: 4,411-426$.

Hendriks, Carolyn M. 2006. When the forum meets interest politics: Strategic uses of public deliberation. Politics ja Society 34:4, 571-602. https://doi.org/10.1177/0032329206293641

Hendriks, Carolyn M. 2016. Coupling citizens and elites in deliberative systems: The role of institutional design. European Journal of Political Research 55:1, 43-60.

https://doi.org/10.1111/1475-6765.12123

Hendriks, Carolyn M. ja Kay, Adrian. 2019. From “opening up” to democratic renewal: Deepening public engagement in legislative committees. Government and Opposition 54:1, 25-51. https://doi.org/10.1017/gov.2017.20

Jäntti, Anni, Airaksinen, Jenni ja Haveri, Arto. 2017. Osallistuminen julkishallinnon legitimiteettikysymyksenä. Teoksessa Pia Bäcklund, Jouni Häkli ja Harry Schulman (toim.), Kansalaiset kaupunkia kehittämässä. Tampere: Tampere University Press, 34-57.

Karjalainen, Maija ja Rapeli, Lauri. 2015. Who will not deliberate? Attrition in a multi-stage citizen deliberation experiment. Quality ja Quantity 49, 407-422.

Karlsson, Martin. 2012. Participatory initiatives and political representation: The case of local councillors in Sweden. Local Government Studies 38:6, 795-815. https://doi.org/10.1080/03003930.2012.688036.

Koskimaa, Vesa ja Rapeli, Lauri. 2020. Fit to govern? Comparing citizen and policymaker perceptions of deliberative democratic innovations. Policy ja Politics 48:4, 637-652.

https://doi.org/10.1332/030557320X15870515357288

Kuyper, Jonathan ja Wolkenstein, Fabio. 2018. Complementing and correcting representative institutions: When and how to use mini-publics. European Journal of Political Research 58: 656-675. https://doi.org/10.1111/1475-6765.12306

Lafont, Christine. 2017. Can democracy be deliberative and participatory? The democratic case for political uses of mini-publics. Daedalus 146:3, 85-105. https://doi.org/10.1162/DAED_a_00449bos

Landemore, Hélène. 2020. Open Democracy. Reinventing Popular Rule for the 21st Century. Princeton: Princeton University Press.

Leino, Mikko, Bäck, Maria, Christensen, Henrik Serup, Kulha, K., Setälä, Maija, Strandberg, Kim ja Taskinen, Mari. 2019. Kuntaliitoskysymyksen käsittely Mustasaaren kansalaisraadissa. Politiikka 61:4, 337-363.

List, Christian, Luskin, Robert C., Fishkin, James S. ja Mc Lean, Iain. 2013. Deliberation, single-peakedness, and the possibility of meaningful democracy: Evidence from deliberative polls. Journal of Politics 75:1, 80-95. https://doi.org/10.1017/S0022381612000886

Mansbridge, Jane. 1999. Everyday talk in the deliberative system. Teoksessa Stephen Macedo (toim.), Deliberative politics: Essays on democracy and disagreement. Oxford: Oxford University Press, 211-239.

Mansbridge, Jane, Bohman, James, Chambers, Simone, Estlund, David, Follesdal, Andreas, Fung, Archon, Lafont, Cristina, Manin, Bernard ja Martí, José Luis. 2010. The place of self-interest and the role of power in deliberative democracy. Journal of Political Philosophy 18:1, 64-100.

https://doi.org/10.1111/j.1467-9760.2009.00344.x

Niemeyer, Simon. 2014. Scaling up deliberation to mass publics: Harnessing mini-publics in a deliberative system. Teoksessa Kimmo Grönlund, André Bächtiger ja Maija Setälä (toim.), Deliberative mini-publics: involving citizens in the democratic process. Lanham: Rowman ja Littlefield Publishers, 177-201.

Niessen, Christoph ja Reuchamps, Min. 2019. Designing a permanent deliberative citizens' assembly: The Ostbelgien modell in Belgium. Working Paper Series No. 2019/6. The Centre for Deliberative Democracy ja Global Governance, University of Canberra. 
Núñez, Lidia, Close, Caroline ja Bedock, Camille. 2016. Changing democracy? Why inertia is winning over innovation. Representation 52:4, 341-357. https://doi.org/10.1080/00344893.2017.1317656

Parkinson, John. 2006. Deliberating in the real world: Problems of legitimacy in deliberative democracy. Oxford: Oxford University Press. https://doi.org/10.1093/019929111X.001.0001

Pearse, Hilary. 2008. Institutional design and citizen deliberation. Teoksessa Mark E. Warren ja Hilary Pearse (toim.), Designing deliberative democracy. Cambridge: Cambridge University Press, 70-84.

Sanders, Lynn. 1997. Against deliberation. Political Theory 25:3, 347-376. https://www.jstor.org/stable/191984

Setälä, Maija. 2017. Connecting deliberative mini-publics to representative decision making. European Journal of Political Research 56:4, 846-863. https://doi.org/10.1111/1475-6765.12207

Setälä, Maija ja Smith, Graham. 2018. Deliberative mini-publics. Teoksessa André Bächtiger, John S. Dryzek, Jane Mansbridge ja Mark E. Warren (toim.), The Oxford handbook of deliberative democracy. Oxford: Oxford University Press, 300-314.

Sintomer, Yves, Herzberg, Carsten ja Röcke, Anja. 2008. Participatory budgeting in Europe: Potentials and challenges. International Journal of Urban and Regional Research 32:1, 164-178. https://doi.org/10.1111/j.1468-2427.2008.00777.x

Smith, Graham. 2009. Democratic innovations. Cambridge: Cambridge University Press. https://doi.org/10.1017/CBO9780511609848

Steiner, Jürg, Bächtiger, André, Spörndli, Markus ja Steenbergen, Marco R. 2004. Deliberative politics in action. Cambridge: Cambridge University Press.

Strandberg, Kim, Himmelroos, Staffan ja Grönlund, Kimmo. 2019. Do discussions in like-minded groups necessarily lead to more extreme opinions? Deliberative democracy and group polarization. International Political Science Review 40:1, 41-57.

Suiter, Jane 2018. Deliberation in action - Ireland's abortion referendum. Political Insight 9:3, 30-32. https://doi.org/10.1177/2041905818796576

Svensson, Jacob. 2008. It' s a long way from Helsingborg to Porto Alegre: A case study in deliberative democracy in late modernity. Journal of Public Deliberation 4:1, 1-22.

Vandamme, Pierre Étienne, Jacquet, Vincent, Niessen, Christoph, Pitseys, John ja Reuchamps, Min. 2018. Intercameral relations in a bicameral elected and sortition legislature. Politics and Society 46:3, 381400. https://doi.org/10.1177/0032329218789890

Warren, Mark. 2008. Citizen representatives. Teoksessa Mark Warren ja Hilary Pearse (toim.) Designing Deliberative Democracy: The British Columbia Citizens' Assembly. Cambridge: Cambridge University Press, 50-69. https://doi:10.1017/CBO9780511491177.004

Warren, Mark. 2009. Governance-driven democratization, Critical Policy Studies 3:1, 3-13. https://doi:10.1080/19460170903158040

Warren, Mark ja Gastil, John. 2015. Can deliberative minipublics address the cognitive challenges of democratic citizenship? The Journal of Politics 77:2, 562-574. https://doi.org/10.1086/680078

Warren, Mark. 2017. A problem-based approach to democratic theory. American Political Science Review 111:1, 39-53. https://doi.org/10.1017/S0003055416000605

White, Stuart. 2017. Parliaments, constitutional conventions, and popular sovereignty. British Journal of Politics and International Relations 19:2, 320-335. https://doi.org/10.1177\%2F1369148117700657

Young, Iris Marion. 2000. Inclusion and Democracy. Oxford: Oxford University Press. 


\section{KIRJOITTAJATIEDOT}

\section{MIKKO VÄRTTÖ}

HTM, YTM, väitöskirjatutkija

Politiikan tutkimus

Johtamisen ja talouden tiedekunta

Tampereen yliopisto

mikko.vartto@tuni.fi

\section{MAIJA JÄSKE}

VTT, tutkijatohtori

Yhteiskuntatieteen tutkimuslaitos (Samforsk)

Yhteiskuntatieteiden ja kauppatieteiden tiedekunta

Åbo Akademi

maija.jaske@abo.fi

\section{KAISA HERNE}

VTT, professori

Politiikan tutkimus

Johtamisen ja talouden tiedekunta

Tampereen yliopisto

kaisa.herne@tuni.fi

\section{KIMMO GRÖNLUND}

$P D$, professor

Institutet för samhällsforskning Samforsk

Fakulteten för samhällsvetenskaper och ekonomi

Åbo Akademi

kimmo.gronlund@abo.fi 